\title{
Late Miocene molluscs of the Morskaya 2 site (Azov Sea region, Russia)
}

\author{
Pavel D. Frolov, Guzel A. Danukalova, and Eugenia M. Osipova
}

\begin{abstract}
Clays and sands of the Morskaya 2 site in the northeastern Azov Sea region contain an assemblage of freshwater and marine molluscs. The site known since the early twentieth century as "Paludina beds" has been alternatively attributed to either Late Pliocene or Late Miocene. Our study shows that the site yielded two assemblages with one composed of Middle Sarmatian (Bessarabian) marine species (M1) and the other containing freshwater and terrestrial molluscs of late Maeotian age (about 7-6 Ma) (M2) with redeposited Bessarabian marine forms. The former assemblage was dated by the vertebrate fauna to the late Turolian and MN13 unit of the West European mammalian biostratigraphical scheme. This level correlates to the Messinian of the International Chronostratigraphic Chart. Ecological preferences in humidity, vegetation, etc. of the terrestrial and freshwater molluscs indicate the presence of a freshwater body rich in aquatic vegetation with a periodical current and a probable connection with a brackish water body located near the Palaeo-Don river delta. Deciduous forests, bushes, and meadows grew on the banks of this basin. The presented revision of molluscs from Morskaya 2 elucidates the composition and correlations of the late Miocene nonmarine fauna in the southeast Europe and includes a description of molluscan assemblages, a discussion of systematic position of the studied molluscs, and a palaeoenvironmental reconstruction of the freshwater basin and its surroundings.
\end{abstract}

Pavel D. Frolov. Geological Institute of the Russian Academy of Sciences, Pyzhevsky per., 7, 119017, Moscow, Russia. pavlentiy987@mail.ru

Guzel A. Danukalova. Institute of Geology - Subdivision of the Ufa Federal Research Centre of the Russian Academy of Sciences, K. Marx str., 16/2, 450077, Ufa, Russia, danukalova@ufaras.ru Eugenia Osipova. Institute of Geology - Subdivision of the Ufa Federal Research Centre of the Russian Academy of Sciences, K. Marx str., 16/2, 450077, Ufa, Russia. myrte@mail.ru

Key words: Bivalvia; Gastropoda; Neogene; Maeotian; Sarmatian

Submission: 21 October 2018. Acceptance: 9 April 2020.

Frolov, Pavel D., Danukalova, Guzel A., and Osipova, Eugenia M. 2020. Late Miocene molluscs of the Morskaya 2 site (Azov Sea region, Russia). Palaeontologia Electronica, 23(1):a20. https://doi.org/10.26879/936

palaeo-electronica.org/content/2020/3013-molluscs-from-morskaya-2-site 


\section{INTRODUCTION}

The Morskaya 2 site $\left(47^{\circ} 17^{\prime} \mathrm{N}, 39^{\circ} 06^{\prime} \mathrm{E}\right)$ is located on the northern shore of the Taganrog Gulf of the Azov Sea in the vicinity of the Morskaya railway station (North-Caucasian Railway), $15 \mathrm{~km}$ to the north-east of the city of Taganrog (Figure 1). This area belongs to the Neklinovsky District of the Rostov Region of the Russian Federation. Since the end of the nineteenth century, many researchers have studied the Neogene and Quaternary deposits of the region, their molluscan and mammalian faunas, etc. (e.g., Bogachev, 1910, 1924, 1961; Khmelevskaya, 1927; Moskvitin, 1932; Gromov, 1948; Rodzyanko, 1981; Popov, 1962, 1983).

The Morskaya 2 site was first described by Bogachev (1924), who referred to the site as the "Paludina beds of the Morskaya station" because of numerous Viviparus (=Paludina) shells found here in greenish-grey clays and grey sands. The age of the deposits with Viviparidae has been a matter of debate for a long time: the deposits were considered either of Akchagylian (Late PlioceneEarly Pleistocene) (Popov, 1962; Vasiliev, 1969) or Khersonian (Late Miocene) age (Bogachev, 1961; Kolesnikov, 1940) (Figure 2). In the early 2000s, new data on molluscs and vertebrates (fishes, amphibians, reptiles, birds, and large and small mammals) were obtained, suggesting these deposits to be of late Miocene (Titov et al., 2006; Titov and Tesakov, 2013).

\section{GEOLOGICAL SETTING}

The studied area is located in the semi-arid steppe zone in the south of European Russia and belongs to the plain adjacent to the northern coast of the Azov Sea. This plain elevated to about $40 \mathrm{~m}$ above sea level of the Taganrog Gulf is strongly dissected by gently sloping ravines and river val-

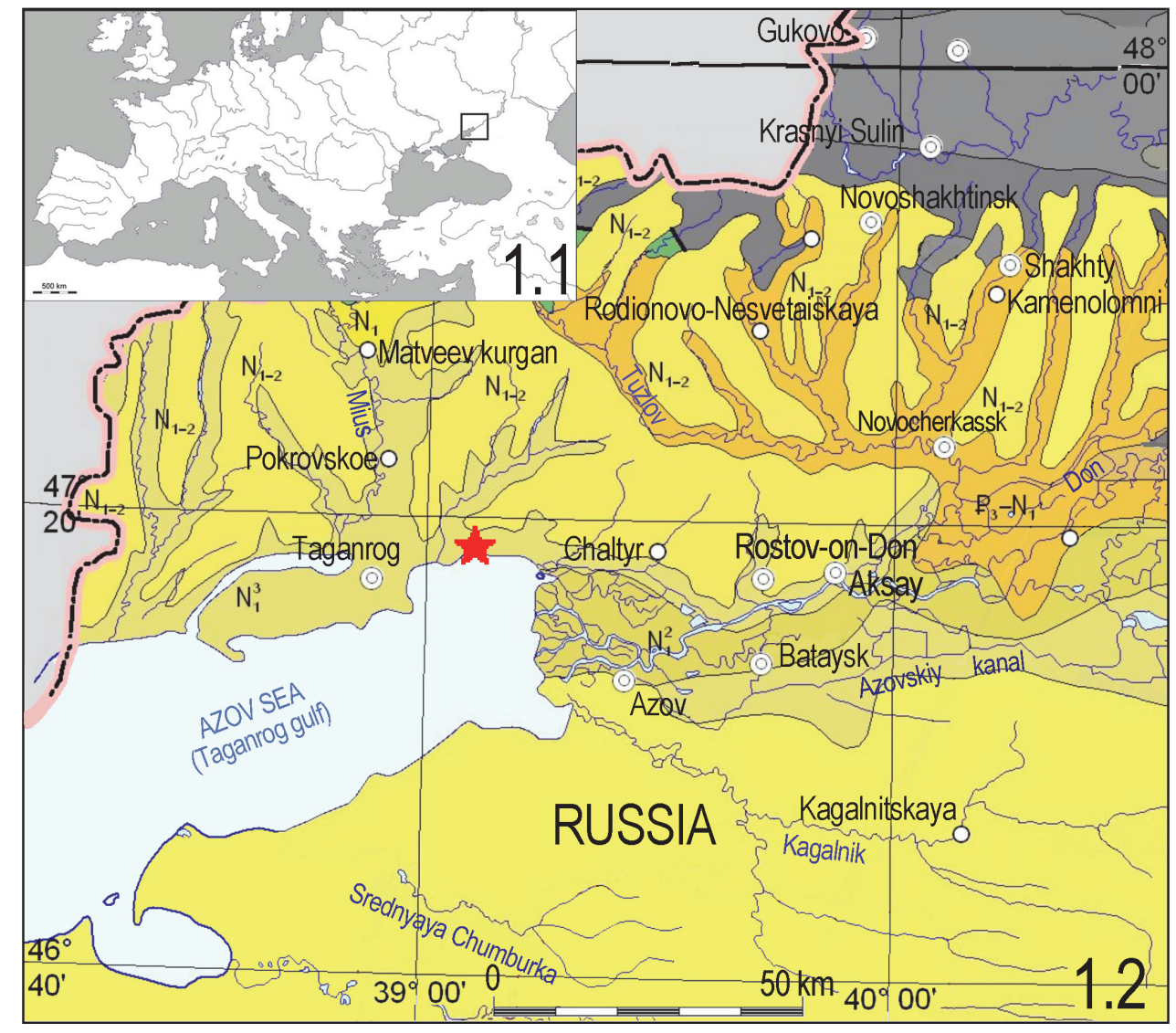

FIGURE 1. 1, General scheme of the territory: black rectangle - position of the studied area. 2, geological map (Geological Map of the southern Federal district of the Russian Federation, 2013) showing the location of the Morskaya 2 site in the northeastern part of the Azov Sea. $\mathrm{P}_{3}-\mathrm{N}_{1}$ - Upper Series of the Paleogene System (Oligocene) - Lower Series of the Neogene System (Miocene); $\mathrm{N}_{1-2}-$ Neogene System (Miocene - Pliocene stages); $\mathrm{N}_{1}$ - the Miocene; $\mathrm{N}_{1}{ }^{3}$ - Upper Miocene; grey colour indicates the Carboniferous System, green - Cretaceous System, red star - the Morskaya 2 site location. 

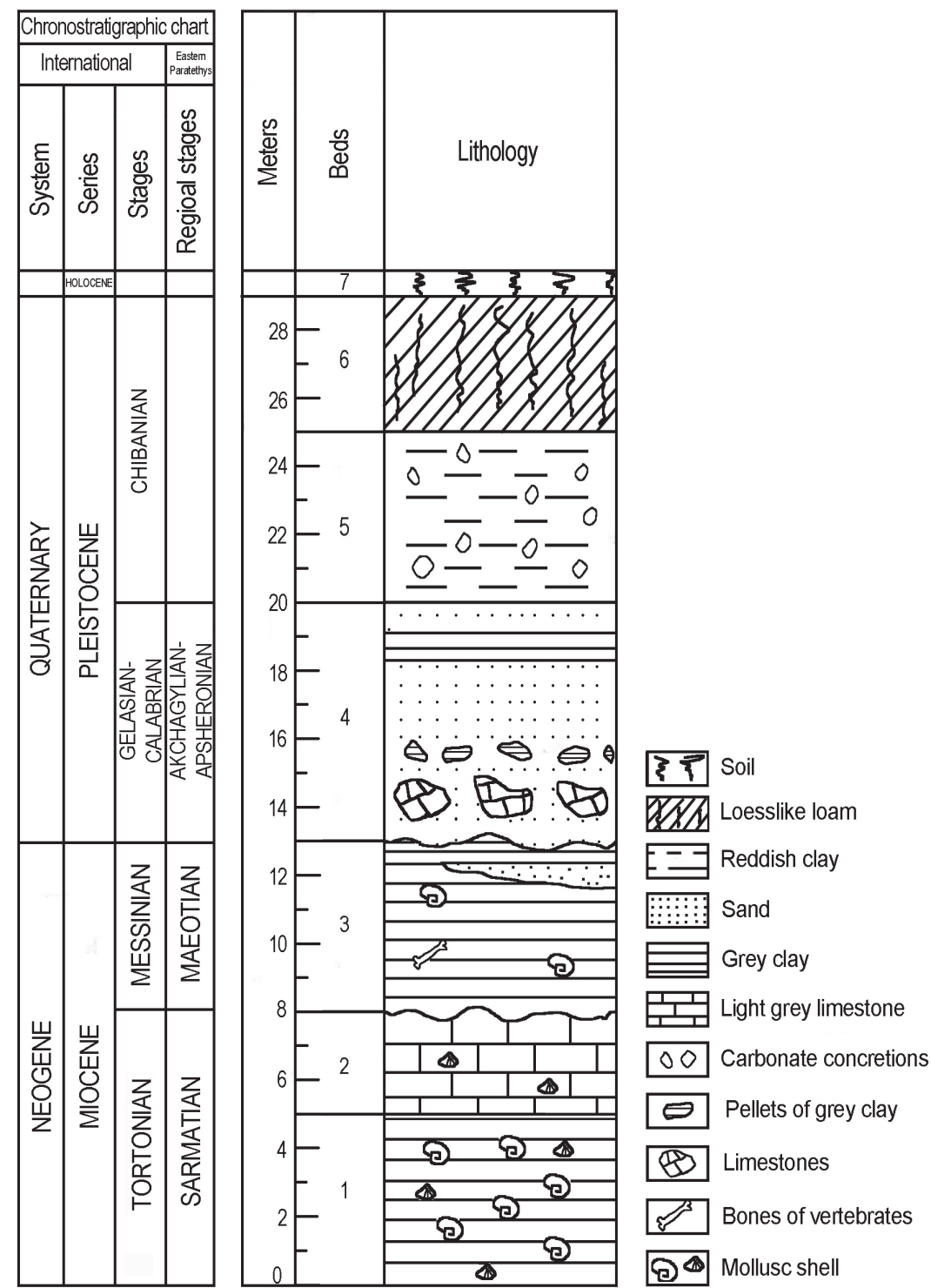

FIGURE 2. Lithological-stratigraphical column of the Morskaya 2 section.

leys flowing south from the Donbass region. Watersheds reach a height of around $100 \mathrm{~m}$ above sea level and belong to the north-western part of the Azov-Kubanian Depression of the Rostov arch (Azov anticline), which is a dipping continuation of the Ukrainian crystalline massif (Pogrebnov et al., 1970).

Middle Miocene (Karaganian and Konkian), Upper Miocene (Sarmatian and Maeotian), Pliocene, and Quaternary deposits are known in this region (Alexandrova et al., 1984; Rodzyanko, 1986). Sea-level rise led to inundation of this area during the Sarmatian, but later, during the Maeotian, seawaters abandoned the territory (Rodzyanko, 1986; Popov et al., 2004). Nowadays numerous landslides cover Neogene outcrops of the Taganrog Gulf cliffs and slopes of the ravines complicating field investigation of the Sarmatian and Maeotian deposits. The Neogene deposits in the exposures near Morskaya were described by Bogachev (1924, pp. 80-81), Vasiliev (1969, pp. 22-23), and Titov et al. (2006, pp. 715-717). The generalised section has the following structure (the description is given from the water level upwards) (Figure 2): 1) Dark grey (almost black) clay with marine bivalve and gastropod mollusc shells (up to $5 \mathrm{~m}$ thick). 2) Light yellowish grey and grey clayey limestone with imprints of marine mollusc shells (thickness is up to $3 \mathrm{~m}$ ). Erosional unconformity on top. 3) Greenish-grey dense clay with interlayers of 
grey sands, with shells of freshwater and marine molluscs, and bones of terrestrial vertebrates (up to $5 \mathrm{~m}$ ). Erosional unconformity on top. 4) Light grey horizontally layered quartz sand with interlayers of grey clays in the upper part and with clays balls and fragments of limestone of the layer 2 in the basal part (up to $7 \mathrm{~m}$ ). 5) Reddish-brown clay with carbonate concretions (up to $5 \mathrm{~m}$ ). 6) Loesslike loam (up to $4 \mathrm{~m}$ ). 7 ) The modern soil (up to 0.5 $\mathrm{m})$.

The total thickness of the sediments in the outcrop is about $30 \mathrm{~m}$. Chronostratigraphy of the beds is given in Figure 2 and discussed in the subchapter Age Interpretation of the Studied Mollusc Assemblages."

\section{MATERIAL AND METHODS}

The molluscs from the lacustrine-lagoon sediments (bed 3) and marine sediments (beds 1 and 2) of the Morskaya 2 site were collected by the joint expedition team of the Geological Institute (Moscow) and the Southern Scientific Centre (Rostovon-Don) of the Russian Academy of Sciences. Palynological samples and bones of vertebrates were gathered during field campaigns in 2002-2013 as well. Mollusc shells are of good and moderate preservation. In the laboratory, the shells were cleaned and prepared for measurements, photography, and species identification. Most of the redeposited marine species are represented by internal casts or strongly damaged shells, complicating their identifications.

The authors use the terms of the Neogene Regional Stratigraphic Scheme of the South of the European part of Russia (Nevesskaya et al., 2004, 2005; Popov et al., 2006; Krijgsman et al., 2019).

Systematics is given according to the recommendations of Falkner et al. (2002), Nevesskaya et al. (2013), Sladkovskaya (2017), and Bouchet et al. (2017).

Measurement of shells are made according to the schemes given in Zhadin (1952), Shileyko (1984), Likharev and Rammelmeyer (1952). The following measurements of shells were taken: shell height (HS), shell width (WS), last whorl height $(\mathrm{HLW})$, aperture height (HA), aperture width (WA), bivalve and cap-shaped shell length (LS), shell width to height ratio (WS/HS), last whorl height to shell height ratio (HLW/HS), aperture width to height ratio (WA/HA), and aperture height to shell height ratio (HA/HS). The convexity parameter of a bivalve shell (Con) is based on a single valve.

The studied material is stored in the Institute of Geology, Subdivision of the Ufa Federal
Research Centre of the Russian Academy of Sciences (Ufa) and in the Geological Institute of the Russian Academy of Sciences (Moscow). Photographs of the mollusc shells were performed by the authors on a Stemi $2000 \mathrm{C}$ stereomicroscope with an AxioCam HRc camera (Carl Zeiss AG), Canon D550 camera and by N.M. Falelyukhin on a FMN2, a device for micro- and macrophotography with a Sony a 330 camera.

\section{SYSTEMATIC PALAEONTOLOGY}

\section{General Remarks}

Two mollusc associations were studied: the first one with marine species occurring in beds 1 and 2, and the second one with freshwater, terrestrial, and redeposited marine molluscs found in the bed 3 (Table 1).

Mollusc association 1 (M1). The mollusc shells were collected from the dark grey clay (bed 1) and partly from the limestone (bed 2) (Figures 3 and 4). The association contains seven species belonging to five genera of Bivalvia and 12 species belonging to nine genera of Gastropoda (Figures 3 and 4). All the shells are of good or moderate preservation.

Mollusc association 2 (M2). The molluscs were collected from the greenish-grey clay (bed 3). The collection contains five species belonging to five genera of bivalves and 23 species belonging to 20 genera of gastropods (Figures 5-8). Eleven species of freshwater and three species of terrestrial molluscs are of good preservation; 14 species of marine, one species of freshwater, and one species of terrestrial molluscs are poorly preserved. According to the degree of preservation, the molluscs are subdivided into in situ (autochthonous) and redeposited groups. The autochthonous freshwater molluscs include: Lymnaea Lamarck, 1799; Gyraulus Charpentier, 1837; Borysthenia Lindholm, 1914; Lithoglyphus Pfeiffer, 1828; Viviparus Montfort, 1810; Sphaerium Scopoli, 1777; and Pisidium Pfeiffer, 1821. Terrestrial molluscs are represented by Helicodiscus Morse, 1864; Vallonia Risso, 1826 and Agriolimacidae. We collected 354 $(13.3 \%)$ shells of terrestrial and 2301 (86.7 \%) shells of freshwater molluscs, in total 2655 specimens.

Because the present paper is devoted primarily to the Maeotian complex of freshwater molluscs, we describe here only some of the most common species of the redeposited marine Sarmatian (Bessarabian) molluscs.

Phylum MOLLUSCA Linnaeus, 1758
Class GASTROPODA Cuvier, 1797 
TABLE 1. Distribution of the mollusc species in the Miocene deposits of the Morskaya 2 site.

\begin{tabular}{|c|c|c|c|c|}
\hline \multirow[b]{3}{*}{ № } & \multirow[b]{3}{*}{ Taxa } & \multicolumn{3}{|c|}{ Miocene } \\
\hline & & \multicolumn{2}{|c|}{$\begin{array}{c}\text { Sarmatian marine } \\
\text { conditions }\end{array}$} & \multirow{2}{*}{$\begin{array}{c}\begin{array}{c}\text { Maeotian lake- } \\
\text { lagoon conditions }\end{array} \\
\text { Layer } 3\end{array}$} \\
\hline & & Layer 1 & Layer 2 & \\
\hline 1. & Blinia cf. angulata (d'Orbigny, 1844) & & & 1 \\
\hline 2. & Gibbula (Sarmatigibbula) podolica (Du Bois de Montpéreux, 1831) & 47 & & 8 \\
\hline 3. & G. (Gibbula) pseudoangulata (Sinzov, 1875) & 2 & & 1 \\
\hline 4. & Gibbula sp. & & & 70 \\
\hline 5. & Barbotella intermedia (Radovanović et Pavlović, 1893) & & & 6 \\
\hline 6. & Hydrobia elongata Eichwald, 1830 & 78 & & 1 \\
\hline 7. & Pseudamnicola nympha (Eichwald, 1850) & 6 & & 1 \\
\hline 8. & Dorsanum ignobile (Kolesnikov, 1932) & 5 & & \\
\hline 9. & D. duplicata opinabile (Kolesnikov, 1932) & 34 & & \\
\hline 10. & D. corbiana (d'Orbigny, 1844) & & 7 & \\
\hline 11. & Dorsanum sp. & & & 1 \\
\hline 12. & Acteocina lajonkaireana (Basterot, 1825) & 12 & & 46 \\
\hline 13 & A. okeni (Eichwald, 1850) & 3 & & \\
\hline 14. & Retusa melitopolitana (Sokolov, 1899) & 77 & & 1 \\
\hline 15. & Viviparus cf. maeoticus (Bogachev and Shishkina, 1919) & & & 692 \\
\hline 16. & V. cf. karaganicus Volkova, 1939 & & & 12 \\
\hline 17. & Bithyniidae indet. (operculum) & & & 78 \\
\hline 18. & Lithoglyphus acutus Cobălcescu, 1883 & & & 1410 \\
\hline 19. & Borysthenia cf. pronaticina (Lindholm, 1932) & & & 3 \\
\hline 20. & Lymnaea sp. & & & 1 \\
\hline 21. & Planorbarius sp. & & & 1 \\
\hline 22. & Anisus cf. spirorbis (Linnaeus, 1758) & & & 3 \\
\hline 23. & Gyraulus cf. acronicus (Férrussac, 1807) & & & 94 \\
\hline 24. & Gyraulus sp. & & & 1 \\
\hline 25. & Helicodiscus (Helicodiscus) roemeri (Andreae, 1902) & & & 9 \\
\hline 26. & Vallonia cf. pulchella (Müller, 1774) & & & 1 \\
\hline 27. & Vertigo sp. & & & 1 \\
\hline 28. & ? Deroceras sp. (Agriolimacidae) & & & 344 \\
\hline 29. & Sphaerium cf. rivicola Lamarck, 1818 & & & $4(4 r+4 I)$ \\
\hline 30. & Pisidium sp. & & & 4 juv. $(3 r+4 I)$ \\
\hline 31. & Polititapes ponderosa (d'Orbigny, 1844) & $12(12 \mid+2 r)$ & & \\
\hline 32. & P. vitaliana, (d'Orbigny, 1844) & $49(38 I+49 r)$ & & \\
\hline 33. & Veneridae indet. & & & $18(16 r+18 I)$ \\
\hline 34. & Sarmatimactra fabreana (d'Orbigny, 1844) & $3(3 \mid+2 r)$ & & $1(1 r+11)$ \\
\hline 35. & Ervilia dissita dissita (Eichwald, 1830) & $13(10 \mid+13 r)$ & & \\
\hline 36. & Obsoletiforma obsoleta ingrata (= Cerastoderma) (Kolesnikov, 1929) & $11(10 \mid+11 r)$ & & \\
\hline 37. & O. obsoleta obsoleta (Eichwald, 1830) & $12(81+12 r)$ & & \\
\hline 38. & Obsoletiforma sp. & & & 22 \\
\hline 39. & Plicatiforma fittoni fittoni (d'Orbigny in Murchison et al., 1845) & $15(11++15 r)$ & & $17(5 r+17 l)$ \\
\hline 40. & Cardiidae indet. & & & 48 \\
\hline
\end{tabular}

I - left valve; $r$ - right valve; juv. - juvenile 


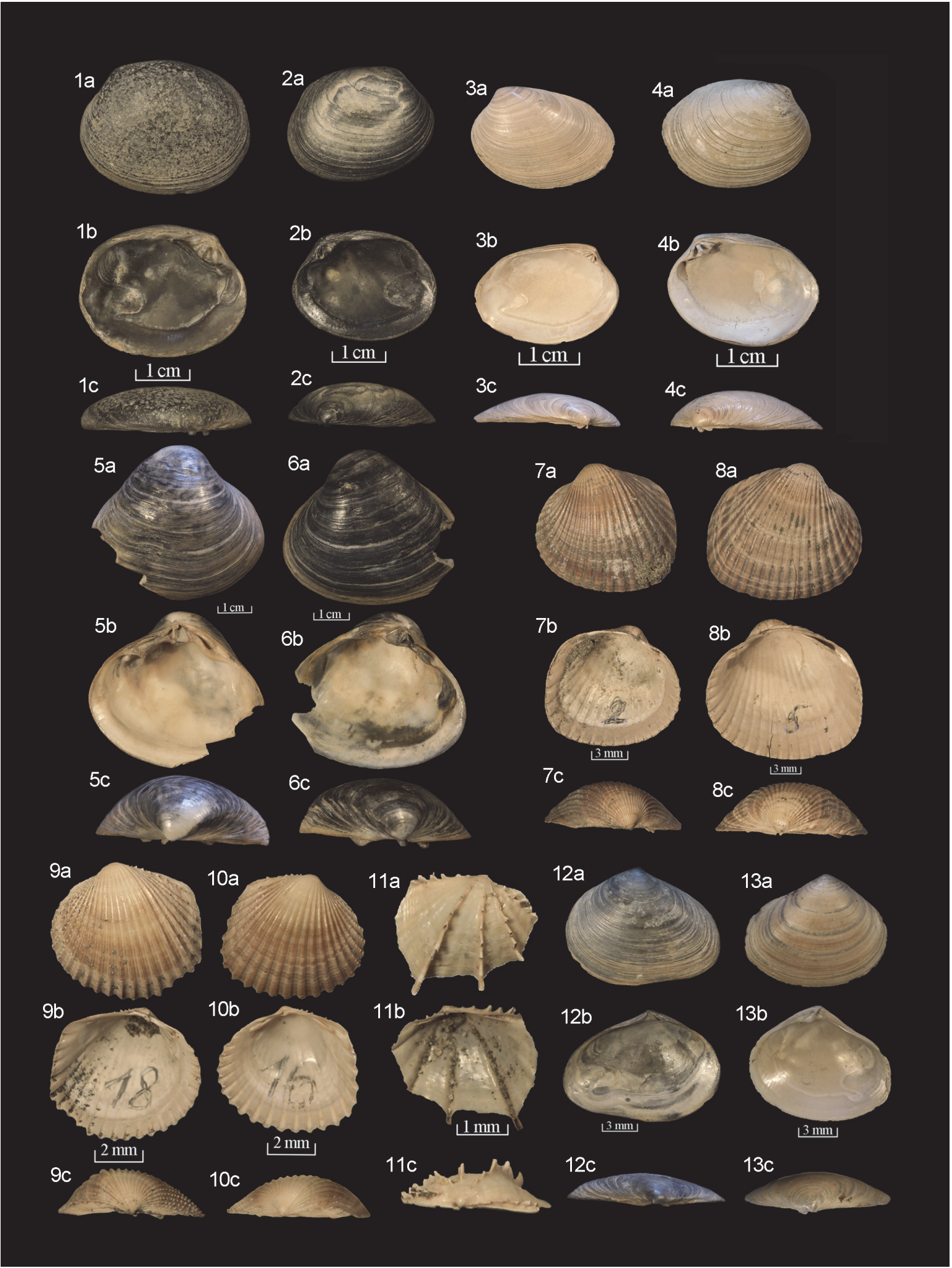

FIGURE 3. Assemblage of the Middle Sarmatian (Bessarabian) marine bivalves (layer 1). 1-2, Polititapes ponderosa (d'Orbigny, 1844). 3-4, Polititapes vitaliana (d'Orbigny, 1844). 5-6, Sarmatimactra fabreana (d'Orbigny, 1844). 7-8, Obsoletiformes obsoletum ingratum (Kolesnikov, 1929). 9-10, Obsoletiformes obsoletum obsoletum (Eichwald, 1830). 11, Plicatiforma fittoni fittoni (d'Orbigny in Murchison et al., 1845). 12-13, Ervilia dissita dissita (Eichwald, 1830). 
Family TECTURIDAE Gray, 1847

Genus BLINIA O. Anistratenko, Bandel and V. Anistratenko, 2006

Blinia cf. angulata (d'Orbigny, 1844)

Figure 8.4

1844 Helcion angulata d'Orbigny, p. 470, pl. 4, figs. 13-15.

1935 Acmaea angulata (d'Orbigny); Kolesnikov, p. 128-129, pl. 19, figs. 12-15.

2006 Blinia angulata (d'Orbigny); O. Anistratenko, Bandel and V. Anistratenko: $p$. 160, fig. 5A.

2007

Blinia angulata (d'Orbigny); O. Anistratenko and V. Anistratenko, p. 358-359, figs. 4B, 8A.

Material. 1 specimen from layer 3 .

Description. The shell is cap-shaped (LS is 2.37 $\mathrm{mm}$; HS is $0.86 \mathrm{~mm}$; WS is $1.8 \mathrm{~mm}$, WS/LS is 0.76 ), not high (flattened). The shell walls are slightly convex and thick. The apex is slightly shifted to the anterior end of the shell (the distance from the anterior edge is $1.4 \mathrm{~mm}$ ). The aperture is oval, the edges are smoothed. The surface of the shell is uneven, rough with a carbonate crust.

Region of distribution and age. Sarmatian of the Eastern Paratethys (O. Anistratenko et al., 2006).

Family TROCHIDAE Rafinesque, 1815

Genus GIBBULA Risso, 1826

Subgenus GIBBULA Risso, 1826

Gibbula (Gibbula) pseudoangulata (Sinzov, 1875)

Figure 4.9, Figure 8.2

1875 Trochus pseudoangulatus Sinzov, p. 52 [erroneously written Trochus pseudoanulatus], pl. 4, figs. 17-18.

1935 Trochus pseudoangulatus Sinzov; Kolesnikov, p. 142-143, pl. 20, figs. 1-3.

2017 Gibbula (Gibbula) pseudoangulata (Sinzov); Sladkovskaya, p.1537-1538, pl. 4, figs. 25-27.

Material. 2 specimens from layer 1 and 1 specimen from layer 3 .

Description. The shell is conical with a sharp spire (HS is $12 \mathrm{~mm}$; WS is $11 \mathrm{~mm}$ ), moderately high (WS/HS is 0.85-0.9), consists of seven convex whorls separated by an almost horizontal surface suture. Near-suture very narrow flat areas are visible. The last whorl is about 0.7 of the height of the shell (HLW/HS). Aperture is round, slightly carved by the penultimate whorl (WA/HA is 0.8 ), and is approximately $0.45-0.55$ of the total shell height $(\mathrm{HA} / \mathrm{HS})$. The outer edge of-aperture is thin; the inner one is thickened. Umbilicus is like a puncture; it can be slightly covered by the inner edge of aperture.
The shell surface sculpture appears after the protoconch and consists of spiral ribs (17 on each whorl). There is a well-developed keel on the periphery of the last whorl. The base of the shell is slightly convex and covered with the same spiral ribs. Growth lines are visible on some shells.

Remarks. The subgenus attribution follows Sladkovskaya (2017).

Region of distribution and age. Middle Sarmatian (Bessarabian) of the Eastern Paratethys (O. Anistratenko and V. Anistratenko, 2012).

Subgenus SARMATIGIBBULA Sladkovskaya, 2017

Gibbula podolica (Du Bois de Montpéreux, 1831)

Figure 4.10, Figure 7.5

1831 Trochus podolicus Du Bois de Montpéreux, p. 42, pl. 3, figs. 1-3.

1850 Trochus podolicus Du Bois de Montpéreux; Eichwald, p. 110, pl. 9, fig. 35.

1935 Trochus podolicus Du Bois de Montpéreux; Kolesnikov, p. 180-182, pl. 24, figs. 7-9.

2017 Gibbula (Sarmatigibbula) podolica (Du Bois de Montpéreux); Sladkovskaya, $p$. 1542-1543, pl. 5, figs. 12-21.

Material. 47 specimens from layer 1 and 8 specimens from layer 3.

Description. The shell is conical with a sharp spire (HS is up to $30 \mathrm{~mm}$; WS is up to $25 \mathrm{~mm}$ ), moderately high (WS/HS is $0.9-1.1$ ), consists of eight flat whorls separated by almost horizontal surface suture. Very narrow flat areas are visible near suture. The last whorl is $0.7-0.8$ of the height of the shell (HLW/HS). Aperture is rounded, pointed in the upper part (WA/HA is $0.8-1.0$ ), and is approximately $0.45-0.55$ of the total shell height $(\mathrm{HA} / \mathrm{HS})$. The outer edge of aperture is thin; the inner one is thickened. Umbilicus is slit-like and can be completely covered by the inner edge of aperture.

The shell surface sculpture appears after the protoconch and consists of wide box-shaped spiral ribs (usually four on each whorl). The upper and lower ribs on each whorl are more developed than the two middle ribs. The lower rib forms a keel with tubercles along the periphery of the last whorl. The base of the shell is slightly convex and covered with spiral ribs (usually 5). Between the ribs, both on the spire and adumbilical, thin spiral threads often present. Strong growth lines are visible as well.

Region of distribution and age. Early and Middle Sarmatian of the Central and Eastern Paratethys (O. Anistratenko and V. Anistratenko, 2012).

Genus BARBOTELLA Cossmann, 1918 Barbotella intermedia (Radovanović and Pavlović, 


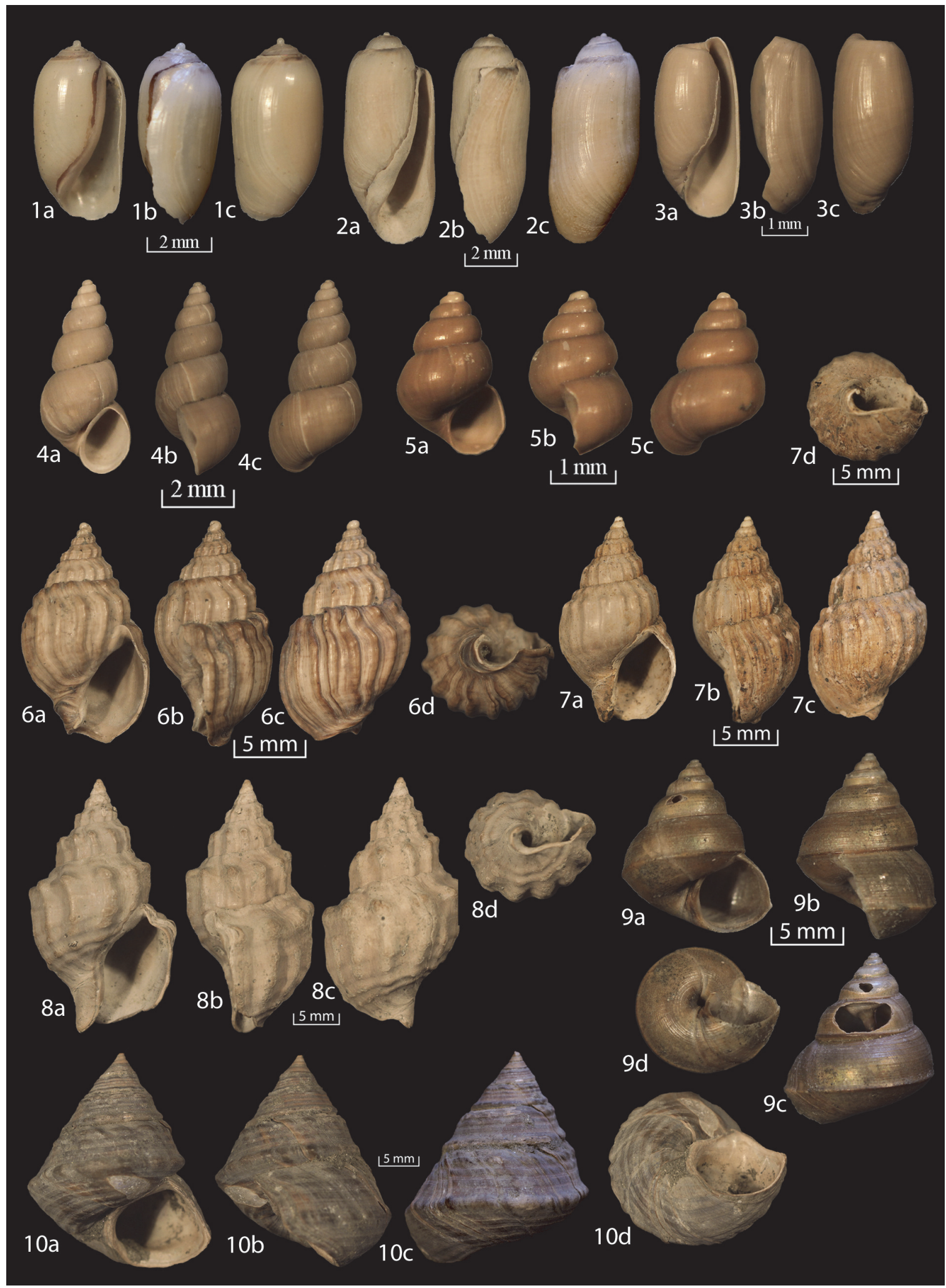

FIGURE 4. Assemblage of the Middle Sarmatian (Bessarabian) marine gastropods (layers 1 and 2). 1, Acteocina lajonkaireana (Basterot, 1825). 2, Acteocina okeni (Eichwald, 1850). 3, Retusa melitopolitana (Sokolov, 1899). 4, Hydrobia elongata Eichwald, 1830. 5, Pseudamnicola nympha (Eichwald, 1850). 6, Dorsanum duplicata opinabile (Kolesnikov, 1932). 7, Dorsanum corbiana (d'Orbigny, 1844). 8, Dorsanum ignobile (Kolesnikov, 1932). 9, Gibbula (Gibbula) pseudoangulata (Sinzov, 1875). 10, Gibbula (Sarmatigibbula) podolica (Du Bois de Montpéreux, 1831). 
1893)

Figure 8.7

1892

1893

Turbo barboti Toula, p. 435, pl. 4, fig 14. Turbo hörnesi var. intermedius Radovanović and Pavlović, p. 128, pl. 1, fig. 5.

1930 Trochus omaliusii var. intermedia (Radovanović and Pavlović); Kolesnikov, p. 63 , pl. 4, figs. 102-106.

1932

Trochus omaliusii var. intermedia (Radovanović and Pavlović); Davitashvili, p. 58 , pl. 8 , figs. $16-19$.

1935 Barbotella intermedia (Radovanović and Pavlović); Kolesnikov, p. 207, pl. 26, figs. 21-22.

1974

Barbotella intermedia (Radovanović and Pavlović); Volkova, p. 80, pl. 24, fig. 9a, b.

Material. 2 complete specimens and 4 fragments from layer 3.

Description. The shell is round-triangular in shape (HS is $34.1 \mathrm{~mm}$; WS is $26.1-30.1 \mathrm{~mm}$, average 28.1; WS/HS average is 0.9 ), consists of $5-6$ rounded whorls, separated by a shallow suture. Convex, thick ribs are observed on the shell surface. The last whorl is bulbous (HLW/HS is 0.95). Spire is high and has a cone form, consisting of convex whorls. Umbilicus is closed by the inner edge of aperture. Aperture is rounded, large, pointed in the upper part (HA is 15.4-17.2 mm, average 16.2; WA is $13.4-14.0 \mathrm{~mm}$, average 13.7 ; WA/HA is $0.8-0.9$, average 0.85 ) and is about $1 / 2$ of the total shell height $(\mathrm{HA} / \mathrm{HS}$ is 0.5$)$. Aperture edges are thickened. Spiral growth lines that coincide with ribs are visible on the shell surface.

Remarks. This species was described by Toula (1892) as Turbo barboti, but he also used the same name for almost smooth forms from Bulgaria in 1877. As a result, Kolesnikov (1935) used the name "intermedia" for ribbed forms, proposed earlier by Radovanović and Pavlović (1893).

Region of distribution and age. Sarmatian of the Eastern Paratethys (O. Anistratenko and V. Anistratenko, 2012).

Family HYDROBIIDAE Stimpson, 1865

Genus HYDROBIA Hartmann, 1821

Hydrobia elongata (Eichwald, 1830)

Figure 4.4, Figure 7.3

$1830 \quad$ Rissoa elongata: Eichwald, p. 218.

1850 Rissoa elongata Eichwald; Eichwald, p. 131, pl. 10, fig 15.

1853 Rissoa elongata Eichwald; p. 272, pl. 10, fig. 15.

non 1853 Litorinella acuta Eichwald, p. 292 (syn. Bulimis elongatus magontianus Faujas de St. Fond: p. 376, pl. 58, fig. 5-8).
1856

1935

Paludina frauenfeldi Hörnes, p. 582, pl. 47, fig. 18.

Hydrobia elongata (Eichwald); Kolesnikov, p. $214-215$, pl. 27 , figs. $18-21$.

Material. 78 specimens from layer 1 and 1 specimens from layer 3.

Description. Shell high conical, with a pointy apex (HS is up to $7.0 \mathrm{~mm}$; WS is up to $3.9 \mathrm{~mm}$ ). WS/HS is $0.45-0.55$, consisting of 6-7 convex whorls separated by a slightly sloping moderately deep suture. The last whorl is rounded and is about $0.5-0.6$ of the shell height $(\mathrm{HLW} / \mathrm{HS})$. Aperture is oval, oblique, pointed in the upper part (WA/HA 0.65), and is approximately $1 / 3$ of the total shell height (HA/HS 0.3). Aperture edges are thin, not thickened. Umbilicus is slit-like, covered by the inner edge of aperture. The shell surface is smooth; growth lines are visible.

Remarks. Hörnes (1856) proposed a new name for Rissoa elongata (Eichwald, 1853, p. 272, pl. 10, fig. 15) as Paludina fraunfeldi, due to the fact that the name elongata for genus Paludina was already used by Sowerby (Hörnes, 1856). Kolesnikov (1935) restored the name given by Eichwald (1830).

Region of distribution and age. Early and Middle Sarmatian of the Central and Eastern Paratethys (O. Anistratenko and V. Anistratenko, 2012).

Genus PSEUDAMNICOLA Paulucci, 1878

Pseudamnicola nympha (Eichwald, 1850)

Figure 4.5

1850

Paludina nympha: Eichwald, p. 135, pl. 10, fig. 27.

1935 Amnicola nympha (Eichwald); Kolesnikov, p. 218 , pl. 27 , figs. $38-40$.

Material. 6 specimens from layer 1 and 1 specimens from layer 3 .

Description. The shell is conical with a pointy apex (HS is $2.5 \mathrm{~mm}$, WS is $1.75 \mathrm{~mm}$ ), moderately high (WS/HS is 0.6 ), consisting of 5 rounded whorls, separated by an almost horizontal moderately deep suture. The last whorl is rounded and is about 0.7 of the shell height (HLW/HS). Aperture is oval, may be slightly oblique, pointed in the upper part (WA/HA is 0.7 ), and is approximately 0.4 of the total shell height $(\mathrm{HA} / \mathrm{HS})$. Aperture edges are thin, not thickened. Umbilicus is slit-like, covered by the inner edge of aperture (the degree of cover can vary from almost completely open to practically closed). The shell surface is smooth; growth lines are visible. There are some shells with a weak spiral striation on the last whorl.

Remarks. Shells with a weak striation may refer to P. cyclostomoides Sinzov, 1880. According to Kole- 
snikov (1935), the main difference between these two species is expressed in the presence of sharp spiral ribs on the last two whorls in $P$. cyclostomoides. Because $P$. nympha may also have such ribs, even though not so prominent, our forms were assigned to the described species.

Pseudamnicola nympha (Eichwald, 1850) was placed to the genus Amnicola by Kolesnikov (1939). According to O. Anistratenko and V. Anistratenko (2012), this species belongs to the family Hydrobiidae on account of the embryonic shell structure. Its generic affiliation needs to be specified. Lukeneder et al. (2011) attributed $P$. cyclostomoides to genus Pseudamnicola. As $P$. cyclostomoides is very close to $P$. nympha we attribute this taxon also to genus Pseudamnicola.

Region of distribution and age. Middle Sarmatian (Bessarabian) of the Eastern Paratethys (O. Anistratenko and V. Anistratenko, 2012).

\section{Family NASSARIIDAE Iredale, 1916}

Genus DORSANUM Gray, 1847

Remarks. Lozouet and Galindo (2015) considered Duplicata Korobkov, 1955 as a synonym of Dorsanum Gray, 1847, and the Buccinum duplicatum group as a specific diversification of the Paratethyan Dorsanum (Lozouet and Galindo, 2015).

Dorsanum ignobile (Kolesnikov, 1932)

Figure 4.8

1932

Buccinum ignobile Kolesnikov, p. 112, pl. 4 , figs. 33-36.

1935 Buccinum ignobile Kolesnikov; Kolesnikov, p. 269, pl. 31, figs. 39-40.

1939 Duplicata ignobile (Kolesnikov); Zhizhchenko in Kolesnikov, 1939.

2012 Duplicata ignobile (Kolesnikov); O. Anistratenko and V. Anistratenko, p. 122.

Material. 5 specimens from layer 1.

Description. The shell is conical with a pointy apex (HS is $28-30 \mathrm{~mm}$; WS is $16-18 \mathrm{~mm}$ ), moderately high (WS/HS is 0.6 ) and consists of 7 slightly convex whorls separated by a slightly sloped surface suture. The last whorl is $0.7-0.75$ of the height of the shell (HLW/HS). Aperture is oval, pointed in the upper part (WA/HA is 0.52 ), and is about 0.5 of the total shell height $(\mathrm{HA} / \mathrm{HS})$. The outer edge of aperture is thin; the inner one is tightly adjacent to the shell, forming a thickening. There is a welldeveloped siphonal canal in the lower part of aperture. Shell surface sculpture appears from the second whorl and consists of radial rows of tubercles connected in ribs. The upper tubercle row forms a keel inflection. The surface of the whorls above the tubercles is smooth. In addition to the keel row one more row of tubercles is usually visible on the spire. Up to four such rows can be traced on the last whorl as well. There are two spiral rows of tubercles on adumbilicus, which form actually the lower part of the radial rows. Adumbilicus is also covered with coarse growth lines.

Region of distribution and age. Middle Sarmatian (Bessarabian) of the Eastern Paratethys (O. Anistratenko and V. Anistratenko, 2012).

\section{Dorsanum duplicata opinabile (Kolesnikov, 1932) \\ Figure 4.6}

1932

Buccinum opinabile Kolesnikov, p. 84, pl. 2, figs. 17-22.

1935

Buccinum opinabile Kolesnikov; Kolesnikov, p. 247, pl. 21 figs. 24-26.

2011 Duplicata duplicata opinabile (Kolesnikov); Kravchenko, p. 17.

Material. 34 specimens from layer 1.

Description. Fusiform shell with a pointy apex (HS is $20 \mathrm{~mm}$; WS is $10 \mathrm{~mm}$ ), moderately high (WS/HS varies from 0.4 to 0.6 , usually 0.5 ), consisting of 6 slightly convex whorls separated by a slightly sloping surface suture. The last whorl is about 0.7 of the shell height $(\mathrm{HLW} / \mathrm{HS})$. Aperture is oval, pointed in the upper part (WA/HA is 0.45-0.55), and is about 0.45 of the total shell height $(\mathrm{HA} / \mathrm{HS})$. The outer edge of aperture is thin; the inner one is tightly adjacent to the shell. There is a well-developed wide siphonal canal in the lower part of aperture.

The shell surface sculpture appears from the second whorl and consists of radial ribs. It is clearly seen on the upper whorls that they consist of 2-3 rows of tubercles connected by spiral lines. The upper row of tubercles forms a keel inflection. The upper whorls surface above this row is smooth. Starting from the fourth whorl, an additional row of tubercles separated from ribs appears in the suture area.

On the last and penultimate whorls tubercles in ribs are not distinguishable, ribs are weakly Sbended. In the normal position of the shell 6-8 ribs are visible on the last whorl. Adumbilicus is covered by coarse growth lines and separated from the fold of the column by a shaft.

Region of distribution and age. Early and Middle Sarmatian of the Eastern Paratethys (Kolesnikov, 1935).

\section{Dorsanum corbiana (d'Orbigny, 1844)}

Figure 4.7

1844 Buccinum corbianum d'Orbigny, p. 464.

1932 Buccinum corbianum d'Orbigny; Kolesnikov, p. 103, pl. 4, figs. 1-5. 

snikov, p. 262, pl. 31, figs. 12-14. tratenko and V. Anistratenko, p. 121.

Material. 7 specimens from layer 2.

Description. Fusiform shell with a pointy apex (HS is about $19 \mathrm{~mm}$; WS is about $10 \mathrm{~mm}$ ), moderately high (WS/HS is $0.55-0.6$ ), consisting of 6 slightly convex whorls separated by a slightly sloping surface suture. The last whorl is about $0.7-0.8$ of the height of the shell (HLW/HS). Aperture is oval, pointed in the upper part (WA/HA is 0.6), and is about $0.45-0.5$ of the total height of the shell $(\mathrm{HA} /$ HS). The outer edge of aperture is thin; the inner one is tightly adjacent to the shell. There is a welldeveloped wide siphonal canal in the lower part of aperture.-

The shell surface sculpture appears from the second whorl and consists of radial ribs. On the upper whorls it is clearly seen that they consist of 3 rows of tubercles connected by spiral lines (usually poorly visible). The upper row of tubercles forms a keel inflection. The surface of the whorls above the tubercles is smooth. Starting from the fourth whorl, in the suture area, an additional row of tubercles spaced apart of ribs appears. The tubercles on the ribs of the last whorl are not always distinguishable. Ribs always look uniform on the last whorl. They are slightly curved. 8-10 ribs are visible on the last whorl in the normal position of the shell. Adumbilicus is covered by coarse growth lines and is separated from the fold of the column by a shaft.

Region of distribution and age. Early and Middle Sarmatian of the Central and Eastern Paratethys (O. Anistratenko and V. Anistratenko, 2012).

Family SCAPHANDRIDAE Sars, 1878 Genus ACTEOCINA Gray, 1847

Acteocina lajonkaireana (Basterot, 1825)

Figure 4.1, Figure 7.7

1825 Bulla lajonkaireana Basterot, p. 22, pl. 1, fig. 25.

1856 Bulla lajonkaireana Basterot; Hörnes, partim, p. 624, pl. 50, figs. 9c-9d.

1911-1928 Tornatina lajonkaireana (Basterot); Friedberg, p. 542, pl. 35, fig. 16.

1935 Bulla lajonkaireana Basterot; Kolesnikov, p. 285-286, pl. 33, figs. 1-4.

1936 Tornatina lajonkaireana (Basterot); Zhizhchenko, p. 266, pl. 25, figs. 15-18, 27-30, pl. 26, figs. 3, 4 .

1953 Acteocina lajonkaireana lajonkaireana (Basterot); Berger, p. 104, pl. 17, figs. 5461. Nevesskaya and Paramonova, p. 276, pl. 28, figs. 22-24.

\section{p. 122 , pl. 15, figs. 11-14}

Material. 12 specimens from layer 1 and 46 specimens from layer 3.

Description. Oval-cylindrical shell with a pointed spire (usually HS is up to $7 \mathrm{~mm}$; WS is up to 3.5 $\mathrm{mm}$ ), may be slightly larger (WS/HS is 0.5 ), consists of 4.5 whorls separated by a horizontal moderately deep suture. Protoconch is heterostrophic. Spire has a wide conical form; whorls are slightly convex. There is a well-defined groove in front of the suture on 1.5-2 last whorls. The last whorl is rounded, about 0.9 of the total shell height (HLW/ $\mathrm{HS})$. Aperture is slit-shaped, widens to the bottom part and becomes rounded; HA/HS is 0.85 . The aperture outer edge is thin; the inner one is tightly adjacent to the whorl, forming a well-visible thickening. The shell surface is smooth; growth lines are visible.

Remarks. Samples from layer 3 are represented mainly by internal casts.

Region of distribution and age. Early Miocene. Europe, North Caucasus, Transcaucasia (Iljina, 1993).

\section{Acteocina okeni (Eichwald, 1850)}

Figure 4.2

1850 Bullina okeni Eichwald, p. 146, pl. 11, fig. 17.

1856 Bulla okeni (Eichwald); Hörnes, partim, p. 624 , pl. 50, fig. 9a-9b.

1935 Bulla okeni (Eichwald); Kolesnikov, p. 288289, pl. 33, figs. 8-10.

2012 Acteocina okeni (Eichwald); O. Anistratenko and V. Anistratenko, p. 123.

Material. 3 specimens from layer 1.

Description. Oval-cylindrical shell with a blunted spire (HS is up to $10 \mathrm{~mm}$; WS is up to $6 \mathrm{~mm}$; WS/ HS is 0.45 ), consists of 4.5 whorls separated by a horizontal moderately deep suture. Protoconch is heterostrophic. Spire has a wide conical form; before the suture; a well-defined groove is present on the last 1.5-2 whorls. The last whorl is rounded and is about 0.9 of the total shell height. Aperture is slit-shaped, and it widens to the bottom part of the shell and becomes rounded (about 0.8 of the total height of the shell). The aperture outer edge is thin; the inner edge is tightly attached to the shell, forming a well-marked thickening. The shell surface is smooth; growth lines are visible. 
Variability. The penultimate whorl is often welldeveloped due to which the spire has a hemispherical shape with a protoconch protruding from above.

Material. Early and Middle Sarmatian of the Central and Eastern Paratethys (O. Anistratenko and V. Anistratenko, 2012).

Family RETUSIDAE Thiele, 1925

Genus RETUSA Brown, 1827

Retusa melitopolitana (Sokolov, 1899)

Figure 4.3

1899 Cylichnina melitopolitana Sokolov, p. 42, pl. 4, figs. 48-52.

1935 Bulla melitopolitana (Sokolov); Kolesnikov, p. 292-293, fig. 39, pl. 33, figs. 21-24.

2012 Retusa melitopolitana (Sokolov); O. Anistratenko and V. Anistratenko, p. 123.

Material. 77 specimens from layer 1 and 1 specimen from layer 3 .

Description. Oval-cylindrical shell, spire is immersed inside the last whorl, forming a funnellike depression (HS is up to $6 \mathrm{~mm}$; WS is up to 3 $\mathrm{mm}$ ), WS/HS is 0.45 in average, consists of 3.5 overlapping whorls separated by a deep suture. The last whorl is rounded and makes up the entire height of the shell. Aperture is slit-shaped, widens to the bottom part and becomes rounded, its upper edge protrudes above the surface of the shell, and aperture height is equal to the last whorl and shell height. The aperture outer edge is thin; the inner edge is tightly attached to the shell, forming a wellmarked thickening. The surface of the shell is smooth; growth lines are visible.

Remarks. Samples from layer 3 are preserved as internal casts.

Region of distribution and age. Early and Middle Sarmatian (Volhynian-Bessarabian) of the Eastern Paratethys (O. Anistratenko and V. Anistratenko, 2012).

Family VIVIPARIDAE Gray, 1847

Genus VIVIPARUS Montfort, 1810

Viviparus cf. maeoticus (Bogachev and Shishkina, 1919)

Figure 5.5

1919 Paludina maeotica Bogachev and Shishkina, p. 38-39.

Material. 692 specimens from layer 3.

Description. The shell is oval-conical with a blunted spire (HS is 6.2-14.2 mm, average 7.8; WS is $6.2-12 \mathrm{~mm}$, average 7.5 ), moderately high (WS/ $\mathrm{HS}$ is $0.84-1.0$, average 0.9 ), consisting of $5-6$ convex whorls, and separated by a moderately deep suture. Spire is short, pointed. The last whorl is rounded and slightly bended to the suture, about $3 /$ 4 or more of the shell height $(\mathrm{HLW} / \mathrm{HS}$ is $0.8-0.9$, average 0.85 ). Aperture has an ovoid form, pointed in the upper part (WA/HA is 0.8-1.1, average 1.0); it is about $2 / 3$ of the total shell height $(\mathrm{HA} / \mathrm{HS}$ is $0.6-$ $0.7 ; 0.61)$. Aperture edges are thin, not thickened. Umbilicus is slit-like, covered by the inner edge. The shell surface is covered by fine hatching. Opercula are not found.

Remarks. This species is very close to Viviparus achatinoides (Deshayes, 1838).

Variability. The form is characterised by high variability in shell size and height-to-width ratio due to sexual dimorphism. Young specimens differ from adult forms in a more rounded and lower shell. Shells of adult forms are more elongated and taller. Region of distribution and age. Late Miocene of the the northeastern Azov Sea region.

Viviparus cf. karaganicus Volkova, 1939

Figure 5.4

1939 Viviparus karaganicus Volkova, p. 19, pl. 1, fig. 5.

1961 Viviparus karaganicus Volkova; Bogachev, p. 277.

Material. 12 specimens from layer 3.

Description. The shell is oval-conical with pointed spire (HS is 7.0-9.2 mm, average 8.0 ; WS is 7.8$12.2 \mathrm{~mm}$, median 9.8), high (WS/HS is 1.1-1.3, average 1.2), and consists of 5-5.5 flattened whorls separated by a shallow suture. The last whorl is rounded, and the bend is clearly visible in the middle of this whorl, it is about $2 / 3$ or more of the shell height (HLW/HS is 0.9-1.0, average 0.96). Aperture has an ovoid form, pointed in the upper part (WA/ $\mathrm{HA}$ is $0.8-1.1$, average 0.96 ), and is about $2 / 3$ of the total shell height (HA/HS is $0.55-0.7 ; 0.69)$. Aperture edges are thin, not thickened. Umbilicus is closed. The shell surface is covered by fine hatching. Opercula were not found.

Remarks. Holotype is stored in the F.N. Chernyshev CNIGR Museum, N 5/5890. Viviparidae with slightly convex whorls and with an inflection on the last whorl are represented by several specimens. Viviparus conoides Mangikian, 1931, from the Khersonian (late Sarmatian) of Ukraine (Gozhyk and Prisyazhnyuk, 1978, p. 59, pl. 36, figs. 7-10) resembles the present specimens but differs in less convex whorls and inflection that is more noticeable on the last whorl. Viviparus karaganicus Volkova, 1939 (pl. 2, fig. 5) from the Karaganian (Middle Miocene) of the North Caucasus has a conical shell with slightly convex whorls and with a smooth keel on the last whorl (Malchevskaya, 1985). Morphologically, this species is closest to 


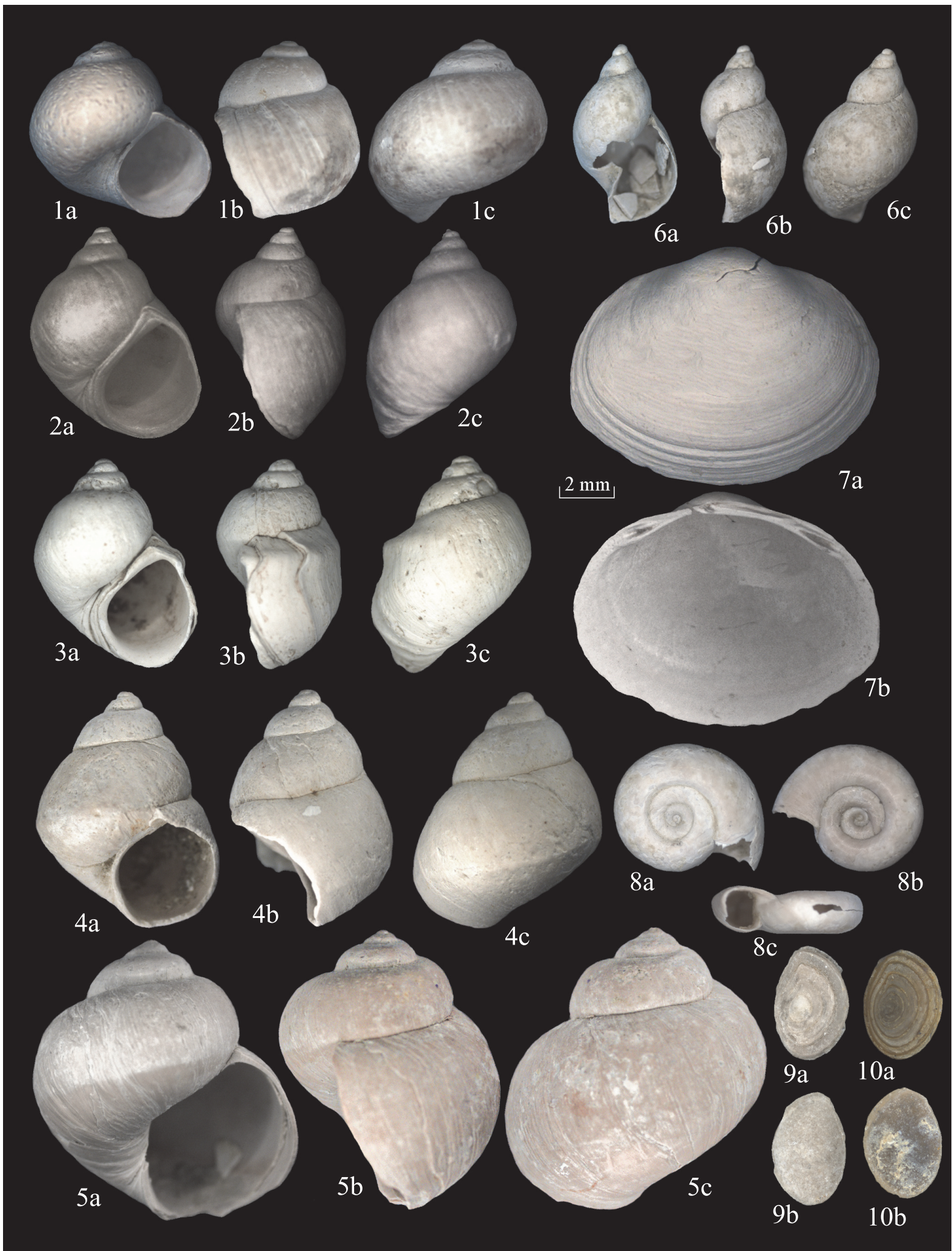

FIGURE 5. Assemblage of the Maeotian freshwater molluscs (layer 3). 1, Borysthenia cf. pronaticina (Lindholm, 1932). 2-3, Lithoglyphus acutus Cobălcescu, 1883; 2, smooth shell; 3, shell with keel. 4, Viviparus cf. karaganicus Volkova, 1939. 5, Viviparus cf. maeoticus (Bogachev and Shishkina, 1919). 6, Lymnaea sp. 7, Sphaerium rivicola Lamarck, 1818. 8, Gyraulus cf. acronicus (Ferrussac, 1807). 9-10, Bithyniidae, opercula. 
the studied specimens. Because of the large age difference between specimens from the Morskaya 2 site and the type locality of the species, we use the open nomenclature for our specimens.

Region of distribution and age. Middle (Karaganian) and Late (Maeotian) Miocene. Stavropol Territory (Volkova, 1939) and the Rostov Region.

\section{Family BITHYNIIDAE Gray, 1857 \\ Bithyniidae indet. \\ Figure 5.9-10}

Material. 78 specimens from layer 3.

Description. Operculum is oval with concentric growth lines, thin ( $L$ is $3.0-3.3 ; W$ is $2.0-2.6 \mathrm{~mm}$ ) or thickened ( $L$ is $4.1-5.0 \mathrm{~mm}$; $W$ is $3.0-3.3 \mathrm{~mm}$ ).

Variability. Appears in the shape of opercula: some of them are flat and oval (Figure 5.9), while others have the shape of a truncated cone with an oval base (Figure 5.10).

Remarks. The two varieties of opercula can belong to different species, and possibly to different genera of the family Bithyniidae, but because no special studies have been conducted on this subject, their systematic identification is impossible.

Family LITHOGLYPHIDAE Tryon, 1866 Genus LITHOGLYPHUS Pfeiffer, 1828

Lithoglyphus acutus Cobălcescu, 1883

Figure 5.2-3

1883 Lithoglyphus acutus Cobălcescu, p. 145, pl. 14, fig. 10.

1896 Lithoglyphus acutus Cobălcescu; Stefanescu, p. 112, pl. 10, figs. 58-63.

1919 Lithoglyphus sarmaticus Bogachev and Shishkina, p. 38-39.

1924 Lithoglyphus acutus Cobălcescu; Bogachev, p. 215, pl. 7, figs. 53, 55, 56.

1929 Lithoglyphus acutus Cobălcescu; Mangikian, p. 171, pl. 1, fig. 9.

1942 Lithoglyphus acutus acutus Cobălcescu; Wenz, p. 48, pl. 15, figs. 195-198.

1962 Lithoglyphus carinatus Popov, p. 94 [nomen nudum].

1972 Lithoglyphus acutus Cobălcescu; Popov, p. 101, pl. 9, figs. 23-26.

1972 Lithoglyphus acutus carinatus Popov, p. 101, pl. 9, figs. 20-23.

Material. 1410 specimens from layer 3 (among them 131 specimens with a noticeable keel inflection).

Description. Oval-conical shell with pointed spire (HS is 6.6-8.2 mm, average 7.3; WS is $4.5-6.3 \mathrm{~mm}$, average 5.6), low (WS/HS is $0.7-0.8$, average 0.74 ), consisting of 5 rounded whorls separated by a shallow suture. The last whorl is rounded, some- times with slight inflection, almost $3 / 4$ of the height of the shell (HLW/HS is $0.8-0.9$, average 0.83 ). Aperture has an ovoid form, large, pointed at the upper part (WA/HA is $0.7-0.8$, average 0.73 ), is about $1 / 2$ of the total shell height (HA/HS is 0.6 $0.7 ; 0.61)$. The outer edge of the aperture is thin; the inner is thickened. Umbilicus is closed by the inner edge of the aperture or in the form of a narrow slit. Fine hatching covers the shell surface.

Remarks. The collection contains numerous Lithoglyphus among which a small group is distinguished due the presence of a keel. It is expressed in smooth bend of the last whorl towards slightly inclined area adjacent to the suture. Some roughness of the last whorl ("hammered surface") on the outer lip side and on the side opposite to the aperture is observed as well.

Bogachev (1924) identified Lithoglyphus naticoides (Pfeiffer, 1828) and L. fluminensis Schmidt, 1847 , in the deposits of the Morskaya 2 site. Popov (1972, p. 101-102) considered that the comparison with Lithoglyphus naticoides as incorrect, and argued that Lithoglyphus from the Morskaya 2 site differs from $L$. fluminensis in the higher and more pointed spire. Popov (1972) attributed the Lithoglyphus of the Morskaya 2 site to the species Lithoglyphus acutus Cobălcescu, 1883. Comparison of specimens from our collection with images of $L$. acutus given by different authors (Cobălcescu, 1883; Stefanescu, 1896; Bogachev, 1924; Mangikian, 1929; Wenz, 1942; Popov, 1962, 1972) confirmed this attribution.

Bogachev and Shishkina (1919) described a shell with a keel as a new species Lithoglyphus sarmaticus. The drawing of this species (Bogachev and Shishkina, 1919, p. 38) demonstrates clearly visible keel on the last whorl. Later this species was mentioned only by Kolesnikov (1934); Bogachev did not use this species name in his publications anymore.

Popov (1962) attributed Lithoglyphus with a keel also as a new species Lithoglyphus carinatus, but without descriptions or images (nomen nudum). Later Popov (1972, p. 101) described the Akchagylian Lithoglyphus of the Akkulaevo site in Fore-Urals and synonymised the species $L$. carinatus G. Popov under L. acutus Cobălcescu Popov (1972) noticed that both species are morphologically similar and that the keel is present occasionally. For these Lithoglyphus with keel he described new subspecies - Lithoglyphus acutus carinatus $\mathrm{G}$. Popov (1972, 101, pl. 9, fig. 20-23). A slightly concave bend to the suture and a small shaft are also present on the specimens described by 
Cobălcescu for his $L$. acutus from the Dacian Basin (1883, p. 145, tabl. XIV, fig. 10), but absent on the photographs depicting this species given by $\mathrm{S}$. Stefanescu (1896, p. 112, pl. 10, figs. 58-63) and Wenz (1942, p. 48, pl. 15, figs. 195-198). We support the opinion of Popov (1972) and assume that our Lithoglyphus with keel is phenotype of Lithoglyphus acutus, and species Lithoglyphus sarmaticus and Lithoglyphus acutus carinatus are junior synonyms.

Variability. Sometimes obviously pronounced inflection appears at the last rounded whorl, which is clearly visible near the aperture (Figure 5.3).

Region of distribution and age. Late Miocene Pliocene of the northern Black Sea region and Azov Sea region (Popov, 1972).

Family VALVATIDAE Gray, 1840

Genus BORYSTHENIA Lindholm, 1914

Borysthenia cf. pronaticina (Lindholm, 1932)

Figure 5.1

1932 Valvata (Borysthenia) pronaticina Lindholm, p. 17-18, pl. 3, fig. 8 a-h.

1983 Valvata pronaticina Lindholm; Chepalyga, Sidnev, p. 63-64, pl., 2, figs. 1-3.

2007 Valvata pronaticina Lindholm; Sanko, p. 78 , drawing 58/4.

Material. 3 specimens from layer 3 .

Description. Oval-conical shell, with a pointed spire (HS is 4.4-6.5 mm, average 5.2; WS is 4.8$6.6 \mathrm{~mm}$, average 5.4), medium height (WS/HS is 1.0-1.1, average 1.03), consists of 4-4.5 rounded whorls separated by a deep, slightly sloping suture. Protoconch consists of 1,5 whorls. Whorls of the spire are slightly swollen and they grow slowly. The last whorl prevails over the others, strongly inflated (HLW/HS is 0.9). Aperture has an ovate form, large, pointed in the upper part (WA/HA is 0.8-0.9, average 0,85 ), is about $1 / 2$ of the total shell height $(\mathrm{HA} / \mathrm{HS}$ is 0.6$)$. The outer edge of aperture is thin. Umbilicus is open slit-shaped. A thin uneven radial hatching covers shell surface.

Remarks. There are three specimens in our collection, which we attribute to Borysthenia. Morphologically, these specimens demonstrate close similarity to the species Borysthenia pronaticina (Lindholm, 1932) and Borysthenia goldfussiana (Wüst, 1901).

Valvatidae specimens from the Morskaya 2 site differ by their smaller spires from typical Borysthenia pronaticina illustrated by Lindholm (1932, pl. 3 , fig. 8a-h). Our specimens are most similar to $B$. pronaticina from the Strelitza quarry (Early Middle Pleistocene of the upper Don area) (Sanko, 2007, p. 78 , fig. 58/4). In general, shells of Borysthenia from Morskaya 2 also have some similarities with Borysthenia goldfussiana, but they differ in smoother whorls and smoothed inflection of the whorls to the suture. In contrast, Borysthenia goldfussiana has less convex whorls and an angular inflection of the whorl to the suture (Gittenberger et al., 1998). Both Borysthenia pronaticina and Borysthenia goldfussiana are known from the Pliocene and Pleistocene deposits. The former species appeared in the Early Pliocene and is known from the Krutogorsky complex of the Western Siberia (Zykin, 2012). Borysthenia goldfussiana appeared in Northern Europe only in the Early Pleistocene (Tegelen) (Gittenberger et al., 1998). Regarding the late Maeotian age of our samples and their morphological similarity with Borysthenia pronaticina we treat them as Borysthenia cf. pronaticina (Lindholm, 1932).

Region of distribution and age. Late Miocene Pleistocene. Western Siberia, the Southern Urals, the south of Eastern Europe (Sanko, 2007; Zykin, 2012).

Family PLANORBIDAE Rafinesque, 1815 Genus ANISUS Studer, 1820

Anisus cf. spirorbis (Linnaeus, 1758)

Figure 8.3

$1758 \quad$ Helix spirorbis, Linnaeus, p. 770.

1885 Planorbis spirorbis (Linnaeus); Westerlund, p. 73.

1952 Anisus spirorbis (Linnaeus); Zhadin, p. 185, fig. 90.

1955 Paraspira spirorbis (Linnaeus); Danilovskiy, p. 105 , pl. 10, figs. 286-288.

1960 Paraspira spirorbis (Linnaeus); Kirillina, p. 151, pl. 8, figs. 97-98.

1964 Anisus spirorbis (Linnaeus); Ložek, p. 183, fig. 33.

1977 Anisus spirorbis (Linnaeus); Starobogatov, p. 170 , fig. 405.

1998 Anisus spirorbis: Gittenberger, Janssen, Kuijper, Kuiper, Meijer, Velde and Vries, p. 147, figs. 297-299.

2002 Anisus (Anisus) spirorbis (Linnaeus); Glöer, p. 256, add. 278.

2007 Anisus spirorbis (Linnaeus); Sanko, p. 110, fig. 88.

Material. 3 specimens from layer 3.

Description. Planispiral shell (HS is $0.8 \mathrm{~mm}$; WS is $2.4 \mathrm{~mm}$; WS/HS is 3 ), dented evenly from the upper and lower sides. There are 5-6 rounded whorls, slowly growing, convex, covered with longitudinal hatching. Suture is deep. The last whorl is 1.5 times wider than the penultimate one. Shell is flattened at the bottom, and a keel is observed 
along the periphery of the lower edge. Aperture is rounded, with a lip inside. The upper edge of aperture is extended forward.

Remarks. Preservation of shells is in a form of internal casts suggesting redeposition.

Region of distribution and age. Pleistocene Present. European part of Russia, Asia, Europe (Glöer, 2002). Late Miocene of the the northeastern Azov Sea region.

Genus GYRAULUS Charpentier, 1837

Gyraulus cf. acronicus (Férrussac, 1807)

Figure 5.8

1807 Planorbis acronicus Férussac, p. 105

1964 Gyraulus acronicus (Férussac); Ložek, p. 188.

1998 Gyraulus (Gyraulus) acronicus (Férussac); Gittenberger, Janssen, Kuijper, Kuiper, Meijer, Velde and Vries, p. 151, figs. 321323, 363.

2002 Gyraulus (Gyraulus) acronicus (Férussac); Glöer, p. 270, add. 291.

2007 Gyraulus acronicus (Férussac); Sanko, p. 127, fig. 96.

Material. 94 specimens from layer 3.

Description. Planispiral shell (HS is $1.1-1.5 \mathrm{~mm}$, average 1.26; WS is $3.6-4.0 \mathrm{~mm}$, average 3.6 ; WS/ $\mathrm{HS}$ is 2.6-4, average 3.6) consists of 4-4.5 rounded whorls separated by a deep suture, increasing fast and evenly in width. Protoconch consists of 1.5 whorls. The last whorl is about twice as wide as the penultimate one. On the periphery of the last whorl there is an inflection (keel), which is located in the middle or displaced downwards. On the upper side, the whorls are sloping; the lower side is more rounded. Aperture is oval, oblique, slightly lowered, without a lip (HA is 1.1-1.6, average 1.3; WA is 1.32.4 , average 1.7). The shell surface is transversely striated; weak spiral lines are present.

Region of distribution and age. Pliocene - Present. Asia, Europe, America (Glöer, 2002). Late Miocene of the the northeastern Azov Sea region.

Family HELICODISCIDAE Pilsbry in H.B. Baker, 1927

Genus HELICODISCUS Morse, 1864

Helicodiscus (Helicodiscus) roemeri (Andreae, 1902)

Figure 6.2

$1830 \quad$ Helix depressa Eichwald, p. 215.

1853 Helix depressa Eichwald; Eichwald, p. 300301 , pl. 11, fig. 10 a-d.

1902 Hyalinia (Gyralina) roemeri Andreae, p. 89, fig. 3 .
1942

1972

1978

1978

1986

1997

2013

2015

2018

Gyralina roemeri (Andreae); Wenz and Edlauer, p. 93, pl. 4, fig. 12.

Helicodiscus eichwaldi Prisyazhnyuk, p. 132, fig. A.

Helicodiscus eichwaldi Prisyazhnyuk; Gozhyk, Prisyazhnyuk, p. 85, pl. 11, figs. 68.

Helicodiscus (Helicodiscus) roemeri (Andreae); Schlickum, p. 69, fig. 3.

Helicodiscus depressa (Eichwald);

Roshka, p. 40, pl. 1, figs. 10-11.

Helicodiscus (Helicodiscus) depressus (Eichwald); Stworzewicz and Prisyazhnyuk, p. 197-204, figs. 1-4.

Helicodiscus (Helicodiscus) roemeri (Andreae); Stworzewicz, Prisyazhnyuk and Górka, p. 193-194, fig. 5G.

Helicodiscus (Helicodiscus) roemeri (Andreae); Harzhauser, Neubauer, Georgopoulou, Esu, D‘Amico, Pavia, Giuntelli and Carnevale, p. 36, 38, pl. 5, figs. 10-12. Helicodiscus (Helicodiscus) roemeri (Andreae); Harzhauser and Neubauer, p. 110-111, fig. 10A, B.

Material. 9 specimens from layer 3 .

Description. Planispiral shell (HS is 0.85-1.95 $\mathrm{mm}$, average 1.2; WS is $1.7-2.5 \mathrm{~mm}$, average 2.1; WS/HS is 3 ), consists of 3.5-4 rounded whorls, evenly increases in width, convex, covered with longitudinal threads. Suture is deep. Umbilicus is wide and shallow. Aperture is semicircular carved by the last whorl and slightly drawn down, edges are thin (HA is $0.8 \mathrm{~mm}$; WA is $1.0 \mathrm{~mm}$ ); the teeth are absent.

Remarks. Nomenclatorial issues discussed by Stworzewicz et al. (2013) and Harzhauzer et al. (2015).

Region of distribution and age. Middle - Late Miocene (Volhynian to Pannonian/Messinian). Central, Southern and Eastern Europe (Stworzewicz et al., 2013; Harzhauser et al., 2015).

Family VALLONIIDAE Morse, 1864 Genus VALLONIA Risso, 1826

Vallonia cf. pulchella (Müller, 1774)

Figure 6.3

1774

1952

1955

1960

1964
Helix pulchella Müller, p. 30.

Vallonia pulchella (Müller); Likharev, Rammelmeyer, p. 164, fig. 77a.

Vallonia pulchella (Müller); Danilovskiy, p. 88 , pl. 6, figs. 117-118.

Vallonia pulchella (Müller); Kirillina, p. 151, pl. 3, figs. 35-37.

Vallonia pulchella (Müller); Ložek, p. 221, pl. 10/5abc. 


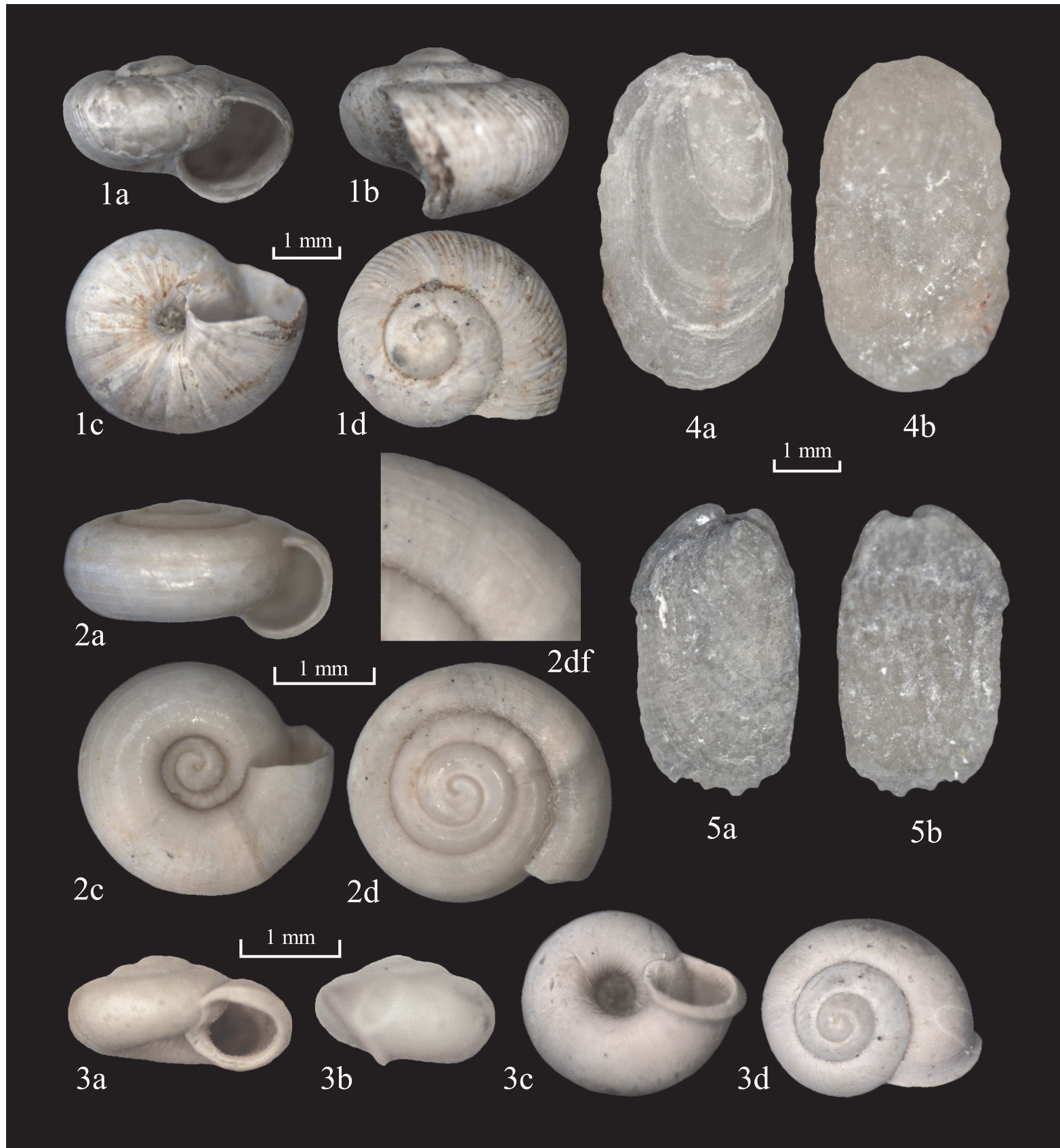

FIGURE 6. Assemblage of the Maeotian terrestrial molluscs (layer 3). 1, cf. Helicella sp. 2, Helicodiscus (Helicodiscus) roemeri (Andreae, 1902). 3, Vallonia cf. pulchella (Müller, 1774). 4-5, ? Deroceras sp.

Material. 1 specimen from layer 3.

Description. Low-conical shell (HS is $1.0 \mathrm{~mm}$; WS is $2.25 \mathrm{~mm}$; WS/HS is 2.25 ) consisting of 3.5 rounded whorls. The last whorl is twice wider as the penultimate one, but not lowered. Suture is deep. Aperture is rounded, edges are slightly outward with a thick white lip (HS is $0.75 \mathrm{~mm}$; WS is 1 $\mathrm{mm})$. Umbilicus is rounded and it slightly widens near the last whorl. Unevenly thin threads striate the shell surface.

Comparison. It differs from Vallonia costata (Müller) in the morphology of the last whorl and aperture. Ribs on whorls are absent.

Region of distribution and age. Late Pliocene Present. Europe, Asia (Danilovskiy, 1955).

? Family AGRIOLIMACIDAE Wagner, 1935

? Genus DEROCERAS Rafinesque, 1815 


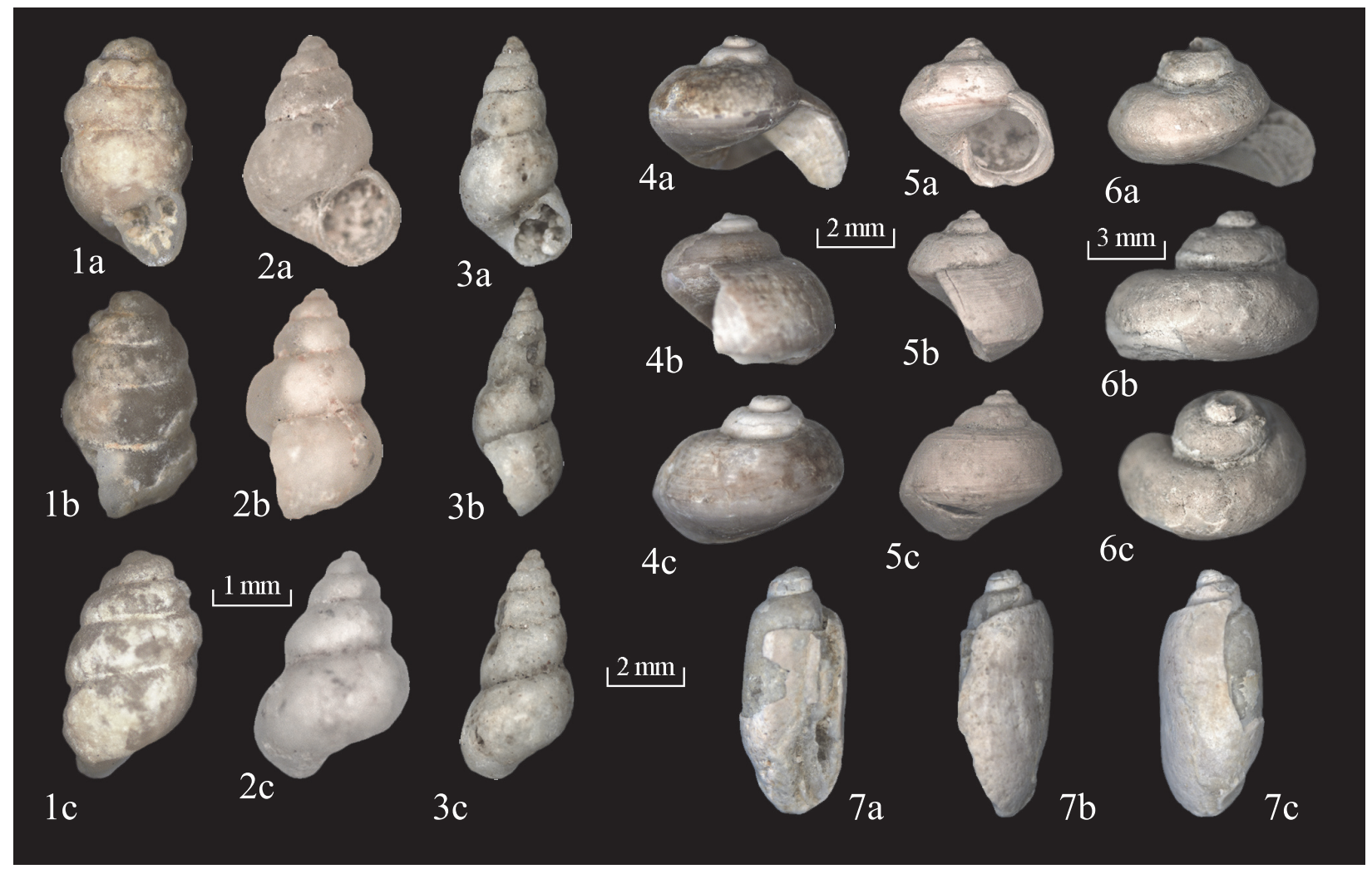

FIGURE 7. Assemblage of the redeposited Miocene marine and terrestrial molluscs. 1, Vertigo sp. 2, Hydrobia enikalensis Kolesnikov, 1935. 3, Hydrobia elongata Eichwald, 1830. 4, Gibbula sp. 5, Gibbula (Sarmatigibbula) podolica (Du Bois de Montpéreux, 1831). 6, Gibbula sp. 7, Acteocina lajonkaireana (Basterot, 1825).

\section{? Deroceras sp.}

Figure 6.4-5

Material. 344 specimens from layer 3.

Description. Oval-oblong vestigial shell (LS is 4.6$6.1 \mathrm{~mm}, 5.2$ in average; WS is $2.5-3.0 \mathrm{~mm}, 2.9$ in average; WS/HS is 0.52-0.6, 0.55 in average), thin, apex shifted to the flank. Edges are uneven. Growth lines are visible on the dorsal side; sculpture on the lower side is absent.

Variability. Appears in an oval to a round-rectangular form of a plate (Figure 6.4-5), apex position, and peculiarities of a growth line position.

Remarks. Fossil slug shells found in the Miocene, Pliocene and Pleistocene undoubtedly belong to different species and most likely to different genera. Since the modern classification is based on the features of the soft body, identification of fossil slugs is generally unreliable (Likharev and Wiktor, 1980). Steklov (1966) conditionally referred slug shells to the genus Limax.

Class BIVALVIA Linnaeus, 1758

Family SPHAERIIDAE Deshayes, 1855 (1820)

Genus SPHAERIUM Scopoli, 1777

Sphaerium rivicola Lamarck, 1818

Figure 5.7

1818

1952

1955

1960

1964

1977

1998

2007

Material. 8 specimens from layer 3 (4 left valves, 4 right valves).

Description. Elongated-rounded shell (HS is 8.0$10.8 \mathrm{~mm}, 9.01$ in average; LS is $10.4-14.0 \mathrm{~mm}$, 11.8 in average; Con. is $2.7-4.4 \mathrm{~mm}, 3.2$ in average) moderately convex, almost equilateral, the 


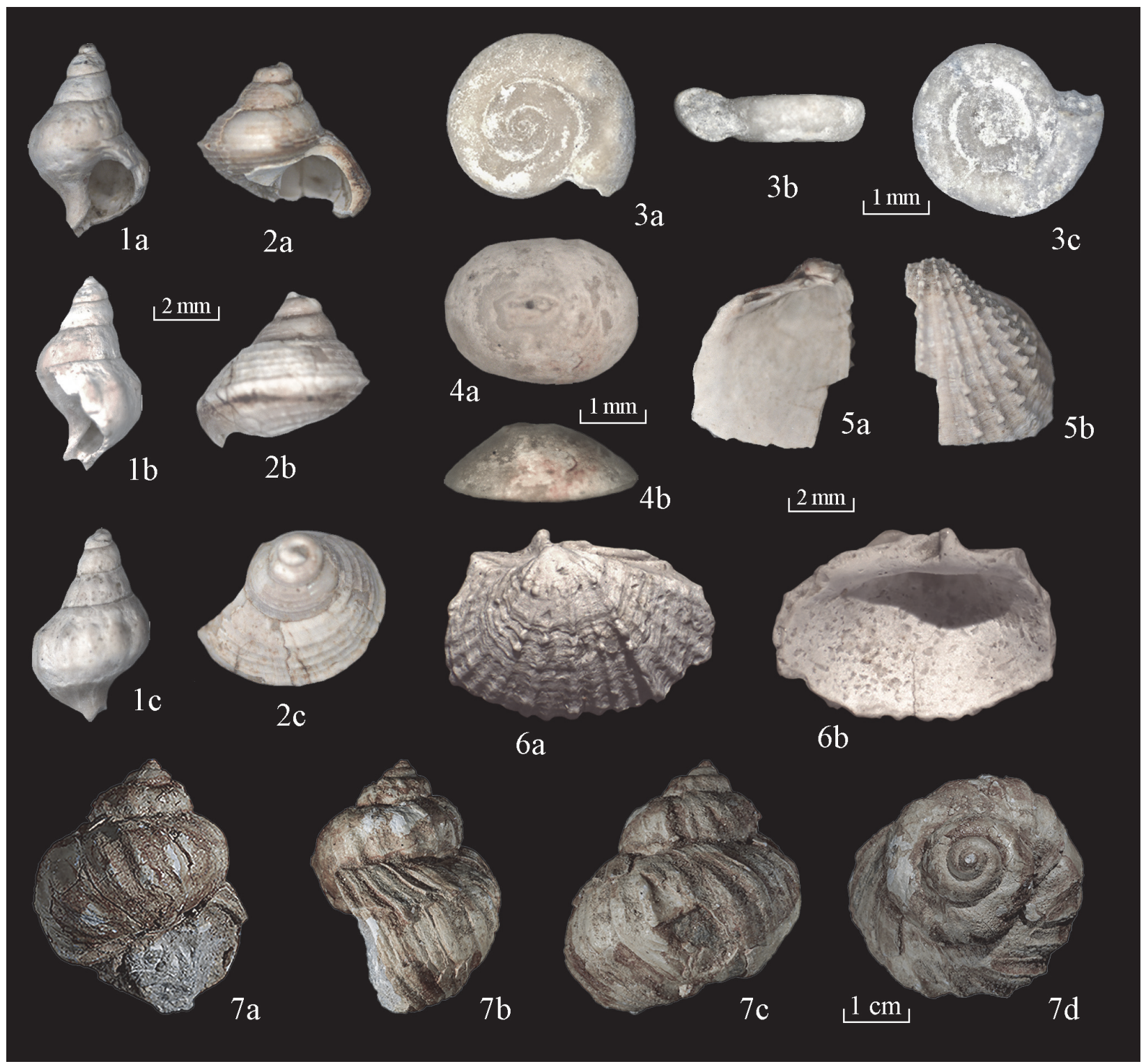

FIGURE 8. Assemblage of the redeposited Miocene marine and terrestrial molluscs. 1, Dorsanum sp. 2, Gibbula (Gibbula) pseudoangulata (Sinzov, 1875). 3, Anisus cf. spirorbis (Linnaeus, 1758). 4, Blinia cf. angulata (d'Orbigny, 1844). 5, Cardiidae indet. (cf. Obsoletiformes). 6, Cardiidae indet. 7, Barbotella intermedia (Radovanović et Pavlović, 1893).

posterior margin wider and slightly longer than the anterior one. Umbo is almost in the middle of the valve, wide, convex but not swollen, slightly protruding above the posterior margin. Dorsal edge is narrow. There are two cardinal teeth in the left valve, the posterior is short and thin, and the anterior is coarse, high, and triangular at the base. Between the two teeth is a wide triangular deepening. Lateral teeth are single. There are two cardinal teeth in the right valve, the posterior one is triangular, with a deep groove at the top, and the anterior is thin and slightly curved. Lateral teeth are doubled. Upper teeth are thinner, lower, and shorter than lower teeth. The deepening between them is short, narrow, and deep.

Region of distribution and age. Late Pliocene Present. European part of Russia and Europe (Gittenberger et al., 1998). Late Miocene of the the northeastern Azov Sea region.

Family VENERIDAE Rafinesque, 1815

Genus POLITITAPES Chiamenti, 1900

Polititapes ponderosa (d'Orbigny, 1844)

Figure 3.1-2

Venus ponderosa d'Orbigny, p. 483, pl. 5, figs. 12-14. 
1932 Tapes gregarius var. ponderosa (d'Orbigny); Davitashvili, p. 33, pl. 2, figs. 1-6.

1935 Tapes gregarius (Partsch in Goldfuss, 1934); Kolesnikov, p. 75, pl. 8, figs. 25-27; [non Venus gregaria Partsch in Goldfuss, 1841 = Polititapes tricuspis (Eichwald, 1829)].

1955 Tapes gregarius (Partsch in Goldfuss, 1934); Merklin, Nevesskaya, p. 61, pl. 17, figs. 11-16.

1969 Tapes tricuspis ponderosus (d'Orbigny); Kojumdgieva, p. 53, pl. 18, figs. 1-3.

$1993 \quad$ Veneripis (Polititapes) ponderosa (d'Orbigny); Nevesskaya, Goncharova, Paramonova, Popov, Babak, Bagdasaryan and Voronina, p. 188, pl. 47, figs. 5-8.

2013 Polititapes ponderosa (d'Orbigny); Neubauer, Harzhauser and Mandic, p. 322.

2013 Polititapes ponderosa (d'Orbigny); Schneider, Mandic and Harzhauser, p. 195.

Material. 12 specimens from layer 1 (12 left valves, 2 right valves).

Description. Shell is round to oval (LS is up to $30.3 \mathrm{~mm}$; HS is up to $25.5 \mathrm{~mm}$; Con. is up to 8 $\mathrm{mm}$ ), large, thick-walled, equivalve. Closure of the valves is dense. Umbo is high, shifted, and strongly turned toward the anterior edge. The anterior branch of the hinge is short, slightly inclined, merges smoothly into a rounded anterior edge. The posterior branch of the hinge is long, smoothly inclined, transforming into the posterior edge with a noticeable blunt angle. Posterior edge broadly rounded. Ventral edge convex, smoothly transforming into adjacent edges, without visible angles. Valves are inequilateral, slightly convex. There is a weak rounded keel from the umbo to the lower posterior corner. Growth lines are clear, often erased on most of the shell, preserved only near the ventral, anterior, and posterior edges. The length of the nymph occupies about two-thirds of the posterior branch of the dorsal edge.

Hinge area is wide, wavy curved. Hinge is massive. Both right and left valve hinge consists of the three cardinal teeth; lateral teeth are absent. The central tooth is a most developed, larger than others are, and divided by a shallow groove. The anterior tooth of the right valve and the posterior of the left valve are smaller; a groove may be developed. The posterior tooth of the right valve and the anterior tooth of the left valve are the weakest; a groove is absent.

The inner surface of the shell with a clear pallial line, the sinus reaches the posterior third of the shell. Muscular scars are oval, deep, and approxi- mately equal in size. Small oval-rounded muscular scars, arranged in a semicircle, are clearly visible under the umbo.

Region of distribution and age. Middle-Late Miocene of Europe. Middle Sarmatian (Bessarabian) of the Eastern Paratethys (Nevesskaya et al., 1993).

\section{Polititapes vitalianus (d'Orbigny, 1844)}

Figure 3.3-4

1844 Tapes vitaliana: d'Orbigny, p. 486, pl. 5, figs. 22-25.

1969 Tapes vitalianus d'Orbigny; Kojumdgieva, p. 52 , pl. 17 , figs. 11,16 .

1993 Venerupis (Polititapes) vitaliana vitaliana (d'Orbigny); Nevesskaya, Goncharova, Paramonova, Popov, Babak, Bagdasaryan and Voronina, p. 187, pl. 46, figs. 5-8.

2013 Polititapes vitalianus (d'Orbigny); Neubauer, Harzhauser and Mandic, p. 322.

2013 Polititapes vitalianus (d'Orbigny); Schneider, Mandic and Harzhauser, p. 195.

Material. 49 specimens from layer 1 (38 left valves, 49 right valves).

Description. Oval-quadrangular shell (LS up to $30.1 \mathrm{~mm}$; HS up to $26 \mathrm{~mm}$; Con. up to $9 \mathrm{~mm}$ ), large, rather thick-walled, equivalve. Closure of valves is dense. Umbo is high, strongly shifted, and turned towards the anterior edge. The anterior branch of the dorsal edge merges smoothly into a narrowed rounded anterior edge. The posterior branch of the dorsal edge is long, slightly inclined, and with a blunt angle, merging into a widely rounded posterior edge. Ventral edge convex merges smoothly into adjacent edges without visible angles. The valves are inequilateral, slightly convex. There is a very weak rounded keel located in the direction from the umbo to the lower posterior corner. However, a keel may be absent. Growth lines are clearly visible, they become rougher downwards, and coarser growth stop lines are also clearly visible. Coloration in the form of horizontal zigzag-like bands can rarely remain on the shells. Nymph occupies about half of the posterior branch of the dorsal edge.

Hinge area is wavy curved. Hinge is massive. Both, the right and the left valves consists of three cardinal teeth, lateral teeth are absent. The central tooth is most developed, larger than others, divided by a shallow groove. The anterior tooth of the right valve and the posterior of the left valve are smaller; a groove may be developed. The posterior tooth of the right valve and the anterior tooth of the left valve are the weakest; a groove is absent. 
The inner surface of the shell shows a clear pallial line, the sinus reaches the posterior third of the shell. Muscular scars are oval, deep, and approximately equal in size. Small oval-rounded muscular scars arranged in a semicircle are clearly visible under the umbo.

Region of distribution and age. Middle-Late Miocene of Europe, Western and Central Ciscaucasia (Nevesskaya et al., 1993).

Family MACTRIDAE Lamarck, 1809

Genus SARMATIMACTRA Korobkov, 1954

Sarmatimactra fabreana (d'Orbigny, 1844)

Figure 3.5-6

1844 Mactra ponderosa (on the plate Fabreana) d'Orbigny, p. 479, pl. 27, figs. 1-6.

1935 Mactra fabreana d'Orbigny; Kolesnikov, p. 50, pl. 5, figs. 1-4.

1969 Mactra (Sarmatimactra) vitaliana fabreana d'Orbigny; Kojumdgieva, p. 22, pl. 5, figs. 2-3.

1976

Mactra (Sarmatimactra) fabreana

d'Orbigny; Iljina, Nevesskaya, and Paramonova, pl. 9, figs. 4-9.

1993

Mactra (Sarmatimactra) fabreana d'Orbigny; Nevesskaya, Goncharova, Paramonova, Popov, Babak, Bagdasaryan, and Voronina, p. 295, pl. 70, figs. 3-6.

Material. 3 specimens from layer 1 ( 3 left valves, 2 right valves) and 1 specimen from layer 3 (1 left valve, 1 right valve, 108 fragments).

Description. Rounded-triangular shell (all the valves of our collection are broken off along the length) (HS up to $46 \mathrm{~mm}$; Con. up to $18 \mathrm{~mm}$ ), large, thick-walled, equivalve. Closure of the valves is dense. Umbo is high, convex, blunt, turned forward. The anterior branch of the hinge edge is inclined and gradually merges into a rounded anterior edge. The posterior branch of the hinge edge is also smoothly inclined and merges smoothly into an angular, slightly abducted posterior edge. The ventral edge is convex. Valves slightly inequilateral, convex. There is a clear rounded keel from the umbo to the posterior lower corner of the valve. Posterior slope is covered by very coarse growth lines, on the other part of shell they are less coarse, thinning when approaching the umbo.

Hinge area is wide and arcuated. Hinge is massive. The right valve it consists of one lambdoid-shaped cardinal tooth and two pairs of lateral teeth. There is a spoon-shaped concavity of the internal ligament between the posterior lateral and cardinal teeth, above which there is a small depression of the outer ligament, separated by a thin plate. There is one lambdoid-shaped cardinal and a pair of single oval-round lateral teeth in the left valve. The cardinal tooth and the concavity of the internal ligament are separated by a thin plate. The inner surface of the shell with a pallial line, sinus is rounded, shallow. The scars of the anterior and posterior muscles are clear, oval. There are visible scars of mantle muscles of irregularly rounded shape above the mantle line.

Remarks. Sarmatimactra is considered a genus distinct from Mactra (Sepkoski, 2002).

Region of distribution and age. The beginning of Late Miocene of Southern and Eastern Europe, Ciscaucasia, Transcaucasia, Mangyshlak, Turkmenia (Nevesskaya et al., 1993).

Family MESODESMATIDAE Gray, 1840 Genus ERVILIA Turton, 1822

Ervilia dissita dissita (Eichwald, 1830)

Figure 3.12-13

1830 Crassatella dissita Eichwald, p. 206; 1853, p. 92, pl. 5, fig. 24.

1932 Ervilia podolica var. dissita (Eichwald); Davitashvili, p. 37, pl. 1, figs. 17-23.

1935 Ervilia dissita (Eichwald); Kolesnikov, p. 39, pl. 3, figs. 9-16.

1955 Ervilia pusilla dissita (Eichwald); Merklin and Nevesskaya, p. 80, pl. 22, figs. 13-21.

1993 Ervilia dissita dissita (Eichwald); Nevesskaya, Goncharova, Paramonova, Popov, Babak, Bagdasaryan and Voronina, p. 306, pl. 72, figs. 37-40.

Material. 13 specimens from layer 1 (10 left valves, 13 right valves).

Description. Oval-triangular shell (LS up to 13.5 $\mathrm{mm}$; $\mathrm{HS}$ up to $10 \mathrm{~mm}$; Con. up to $2.2 \mathrm{~mm}$ ), equivalve. Closure of the valves is dense. Umbo is high, pointed, turned to posterior edge and, usually, displaced to the anterior edge. The anterior branch of the hinge edge is gently sloped and without noticeable angles merges into a widely rounded anterior edge. The posterior branch of the hinge edge is concave and has an S-shaped form without noticeable angles, merges into a rounded, sometimes abducted downward, posterior edge. Ventral edge is slightly convex. Valves are usually inequilateral, slightly convex. The keel is roundish, poorly noticeable. The shell surface is covered with growth lines, which sometimes look like wrinkles.

Hinge area is short. There is one well-developed cardinal tooth and single poorly developed lateral teeth in the right valve hinge. There are two weakly developed cardinal teeth and one posterior lateral tooth in the left valve. There is a triangular deepening for the inner ligament on both valves, closer to the posterior edge. The inner surface of 
the shell is with a clear pallial line, sinus rounded, not deep, pallial tongue with a restriction. The scars of the anterior and posterior muscles are round-oval, clear, and approximately equal in size. Variability. It is expressed in the form of the posterior edge, narrow to broadly rounded, and in the umbo position. Lateral teeth can be reduced, both in the right and left valves.

Region of distribution and age. Early and Middle Sarmatian of south of Eastern Europe, Central Europe and Turkey (Nevesskaya et al., 1993).

Family CARDIIDAE Lamarck, 1809 Genus OBSOLETIFORMES Kojumdgieva, 1969 Obsoletiformes obsoletum ingratum (Kolesnikov, 1929)

Figure 3.7-8

1929 Cardium ingratum Kolesnikov, p. 13, pl. 4, figs. 95-101.

1935 Cardium ingratum Kolesnikov; Kolesnikov, p. 93 , pl. 11, figs. 10-16.

1969 Cardium (Cerastoderma) ingratum (Kolesnikov); Kojumdgieva, p. 30, pl. 9, figs. 7, 8.

1993

Obsoletiforma obsoleta ingrata

(Kolesnikov); Nevesskaya, Goncharova, Paramonova, Popov, Babak, Bagdasaryan, and Voronina, p. 248, pl. 57, figs. 15-18.

2001 Obsoletiformes obsoletus ingratum (Kolesnikov); Nevesskaja, Paramonova, and Popov, p. 180.

Material. 11 specimens from layer 1 (10 left valves, 11 right valves).

Description. Round-triangular shell (LS up to 15.5 $\mathrm{mm}$; HS up to $14.5 \mathrm{~mm}$; Con. up to $5 \mathrm{~mm}$ ), equivalve. Closure of the valves is dense. Umbo is pointed, curved, and slightly shifted forward. The anterior branch of the dorsal edge is gently sloped and without noticeable angles merges into a widely rounded anterior edge. The posterior branch of the dorsal edge forms a well-defined blunt angle with a slightly convex (almost straight) posterior edge. Ventral edge slightly convex. Valves slightly inequilateral, convex. The keel bend is rounded. The shell surface is covered with rectangular ribs. The number of ribs in our material is up to 24 . The intercostal distance is slightly narrower than the ribs. The ribs are smooth. Growth lines and growth stop lines are clearly visible on the shell surface.

There are two cardinal teeth, two anterior lateral teeth (the lower one is more developed), and one posterior lateral tooth in the right valve. In the left valve one cardinal tooth and two lateral teeth, posterior are weakly developed. There is a nymph behind the umbo. Nymph is about $1 / 3$ of the poste- rior branch of the dorsal edge. The pallial line is whole. The scars of the anterior and posterior muscles are round-oval, approximately equal in size. There are grooves corresponding to the ribs on the inner surface. On the edge of the shell they take the form of "serration".

Remarks. Species epithet has been changed from obsoletus to obsoletum (Nevesskaya et al., 2013).

Region of distribution and age. Middle Sarmatian (Bessarabian) of the Eastern Paratethys (Nevesskaya et al., 1993).

Obsoletiformes obsoletum obsoletum (Eichwald, 1830)

Figure 3.9-10

$1830 \quad$ Cardium obsoletum Eichwald, p. 208.

1850 Cardium obsoletum Eichwald; Eichwald, p. 61, pl. 4, fig. 19.

1976 Cerastoderma (Obsoletiforma) obsoletum obsoletum (Eichwald); lljina, Nevesskaya, and Paramonova, pl. 1, fig. 37-48, pl. 2, figs. $25-29$, pl. 3 , figs. $3-26$

1993 Obsoletiforma obsoleta obsoleta (Eichwald); Nevesskaya, Goncharova, Paramonova, Popov, Babak, Bagdasaryan, and Voronina, p. 247, pl. 56, figs. 26-29.

2001 Obsoletiformes obsoletus obsoletus (Eichwald); Nevesskaja, Paramonova, and Popov, p. 180.

Material. 12 specimens from layer 1 (8 left valves, 12 right valves).

Description. Round-triangular shell (LS up to 10.5 $\mathrm{mm}$; HS up to $9.5 \mathrm{~mm}$; Con. up to $2.8 \mathrm{~mm}$ ), equivalve. Closure of the valves is dense. Umbo is pointed, bent forward with a central position. The anterior branch of the dorsal edge is gently sloped and without noticeable angles merging into a widely rounded anterior edge. The posterior branch of the dorsal edge forms a well-defined blunt angle with a slightly convex (almost straight) posterior edge. Ventral edge slightly convex. Valves are almost equilateral, convex. The shell surface is covered with well-developed, triangular-squared ribs. With a gentle front slope and a steep back. The number of ribs is approximately 25 . The intercostal distance is approximately equal to the width of the ribs. Scaly-like outgrowths are often preserved on the first ribs (up to the 6th) in the anterior slope of the shell. They are also present on the three posterior ribs. They are often developed more prominently on the posterior ribs than on the other part of the shell, taking the form of triangular spines. Growth lines are clearly visible, becoming coarse downward. 
There are two cardinal teeth, two anterior lateral teeth (the lower one is more developed), and one posterior tooth in the hinge of the right valve. There are one cardinal tooth and two lateral teeth in the left valve. The short nymph is behind the umbo. The pallial line is whole. The scars of the anterior and posterior muscles are round-oval, equal in size. There are grooves corresponding to the ribs on the inner surface. On the edge of the shell they take the form of "serration."

Remarks. Species epithet has been changed from obsoletus to obsoletum (Nevesskaya et al., 2013). There are only juvenile shells in our collections. Adult specimens can reach 25 , rarely $32 \mathrm{~mm}$ in length (Nevesskaya et al., 1993)

Region of distribution and age. Early and Middle Sarmatian (Volhynian and Bessarabian) of the Eastern Paratethys (Nevesskaya et al., 1993).

Genus PLICATIFORMES Kojumdgieva, 1969

Plicatiformes fittoni fittoni (d'Orbigny in Murchison et al., 1845)

Figure 3.11

1845 Cardium fittoni d'Orbigny in Murchison, Verneuli and Keyserling, p. 499, pl. 43, figs. 38-39.

1932 Cardium fittoni (d'Orbigny in Murchison, Verneuli and Keyserling); Davitashvili, p. 25 , pl. 7 , figs. $18-20$.

1935 Cardium fittoni (d'Orbigny in Murchison, Verneuli and Keyserling); Kolesnikov, p. 115, pl. 17, figs. 10-13.

1955 Cardium fittoni fittoni (d'Orbigny in Murchison, Verneuli and Keyserling); Merklin, Nevesskaya, p. 49, pl. 11, figs. 1-5.

1969 Cardium (Cerastoderma) fittoni fittoni (d'Orbigny in Murchison, Verneuli and Keyserling); Kojumdgieva, p. 50, pl. 16, figs. 15-19.

1976 Cerastoderma (Plicatiforma) fittoni fittoni (d'Orbigny in Murchison, Verneuli and Keyserling); Iljina, Nevesskaya and Paramonova, pl. 2, figs. 3-8.

1993 Plicatiforma fittoni fittoni (d'Orbigny in Murchison, Verneuli and Keyserling); Nevesskaya, Goncharova, Paramonova, Popov, Babak, Bagdasaryan and Voronina, p. 271, pl. 64, figs. 13-16.

$2001 \quad$ Plicatiformes fittoni fittoni (d'Orbigny in Murchison, Verneuli and Keyserling); Nevesskaja, Paramonova and Popov, p. 179.

Material. 15 specimens from layer 1 (11 left valves, 15 right valves) and 17 specimens from layer 3 (5 right valves, 17 left valves).
Description. Round-triangular shell (LS up to 26 $\mathrm{mm}$; HS up to $28 \mathrm{~mm}$; Con. up to $11 \mathrm{~mm}$ ), equivalve. Closure of the valves is dense. Umbo is pointed, bent forward and have a central position. The anterior branch of the dorsal edge is almost horizontal and with blunt angle merging into a widely rounded anterior edge. The posterior branch of the dorsal edge forms a well-defined blunt angle with a slightly convex (almost straight) posterior edge. The ventral edge is slightly convex. Valves are almost equilateral, convex. The keel is expressed in the most developed rib.

The shell surface is covered with five welldeveloped ribs, which have scales and spines. The intercostal distance is much wider than the ribs. In the keel area, weakly developed ribs (radial striae) are visible, reaching the lower edge.

There are two cardinal teeth and one lateral tooth in the hinge of the right valve.

Short nymph is behind the umbo. The pallial line is whole. The scars of the anterior and posterior muscles are round-oval, equal in size. There are grooves corresponding to the ribs on the inner surface.

Region of distribution and age. Late Middle Sarmatian (Late Bessarabian) of the Eastern Paratethys (Nevesskaya et al., 1993).

\section{DISCUSSION}

\section{Age Interpretation of Studied Mollusc Assemblages}

Mollusc association 1 (M1). The age of the marine mollusc assemblage from beds 1 and 2 was determined by the presence of the Bessarabian key species: Gibbula (Sarmatigibbula) podolica, G. (Gibbula) pseudoangulata, Venerupis ponderosa, V. vitaliana, Mactra fabreana, and Plicatiforma fittoni fittoni (Bogachev, 1910, 1924, 1961; Kolesnikov, 1940; Popov, 1962; Vasiliev, 1969; Rodzyanko, 1986).

Mollusc association 2 (M2). The age of the freshwater molluscs from bed 3 can be constrained by its stratigraphic position above the marine Bessarabian black clay and below the Khaprovian sands correlated with the Gelasian Stage of the Quaternary (Vasiliev, 1969, Titov, 2008). Popov (1962, p. 95) noted that the lacustrine Viviparidae have a Kuyalnikian appearance and that Lithoglyphus with a keel are known from the Kuyalnikian (Gelasian) deposits near the Kryzhanovka village. Thus, he interpreted the deposits to be of "Akchagylian-Kuyalnykian" age. Popov (1965), Kolesnikov (1940), and Bogachev (1961) assumed that clay 


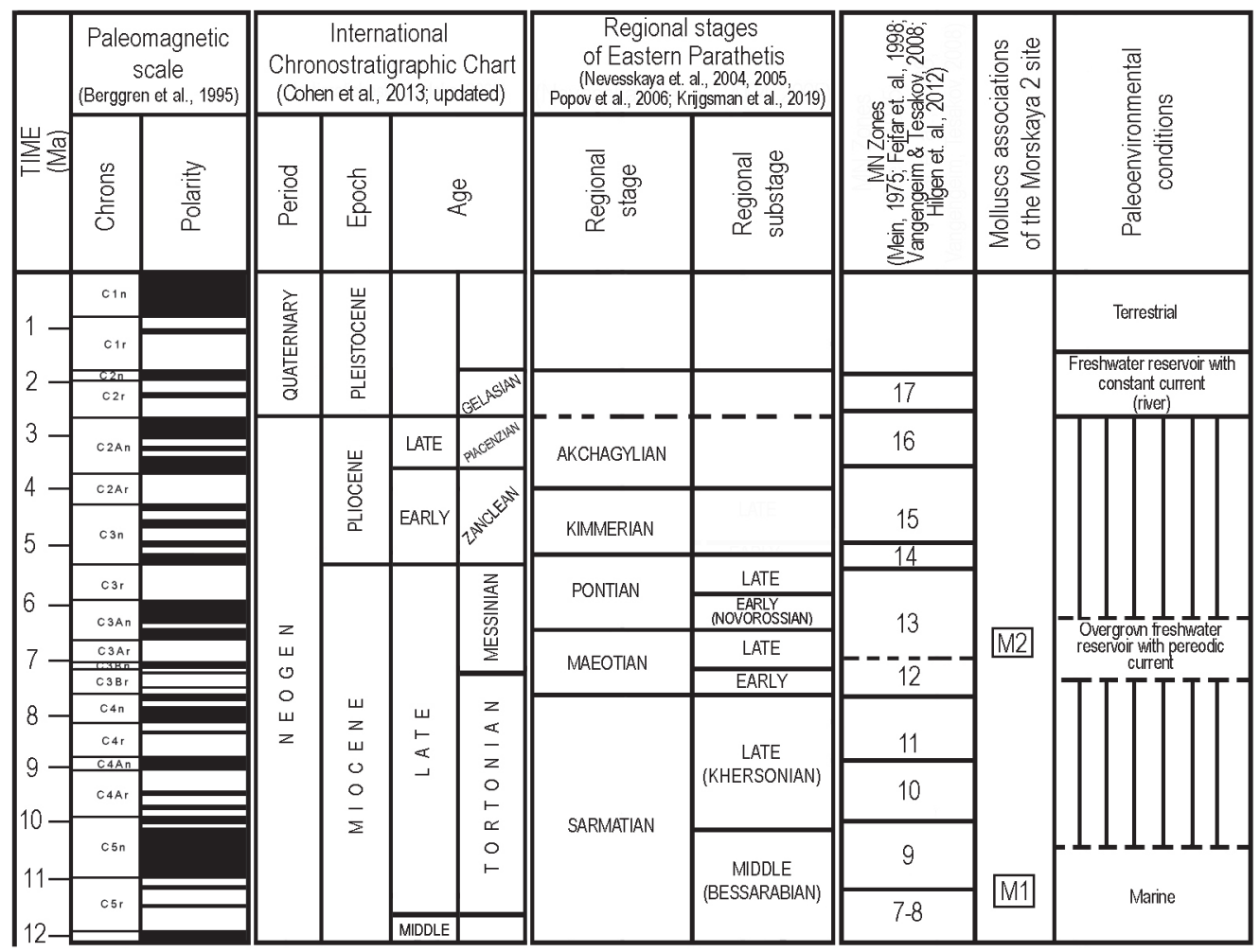

FIGURE 9. Correlation of the studied mollusc complexes of the Morskaya 2 site with the subdivisions of the International Stratigraphical Chart (Berggren et al., 1995; Cohen et al., 2013; updated), the Regional Stratigraphical Scheme of the Neogene deposits of the South of the European part of Russia (Nevesskaja et al., 2004, 2005; Popov et al., 2006; Krijgsman et al., 2019), mammalian zones (Mein, 1975; Fejfar et al., 1998; Vangengeim and Tesakov, 2008; Hilgen et al., 2012) and the palaeogeographical conditions during the period of sedimentation.

with freshwater fauna was accumulated during the regression of the Sarmatian Sea at the end of Miocene. The Assemblage M2 can be more accurately defined on the basis of vertebrate fauna indicative of the late Turolian (lower part of MN13 regional zone) of the European biostratigraphical scheme (Titov and Tesakov, 2013), which correlates with the Messinian and the end of the Maeotian regional stage (Upper Miocene). This age assignment extends age ranges of some of the species to the upper part of the late Miocene. The Assemblage 2 contains some Bessarabian marine molluscs reworked from layers 1 and 2. The source strata of the redeposited terrestrial and freshwater molluscs are not identified. The age of these molluscs was defined as the late Miocene and may cover a range from the Bessarabian to Maeotian.

The alluvial sands of bed 4 correspond to the Khaprovian fluvial unit correlated with Early Pleistocene (MN17) based on the mammalian fauna. This formation is attributed to the palae-Don River sedimentation in its lower course and deltaic parts (Gromov, 1948; Vasiliev, 1969; Titov et al., 2006;
Tesakov et al., 2007; Titov, 2008; Tesakov, 2013). The red-coloured clays of bed 5 ("Scythian Clays") are refereed to the Lower Pleistocene. Loess-like loam of layer 6 was correlated with the Upper Pleistocene. In adjacent sites this layer contains two palaeosol horizons, the Mezin (MIS5) and Bryansk soils (Vasiliev, 1969; Titov et al., 2006, Tesakov et al., 2007) (Figure 9).

\section{Palaeoenvironmental Reconstruction of the Clay Accumulation Environment (layer 3)}

The ecological preferences of modern terrestrial and freshwater mollusc genera identified herein suggest the presence of an overgrown freshwater pond with abundant water vegetation and muddy bottom, which could be either an oxbow or a floodplain lake, as indicated by species of the families Planorbidae and Lymnaeidae. The presence of Viviparus and Lithoglyphus gives evidence of periodical connections with a river, as well as a shallow coastal part of a large river with a weak current. Similar conditions may also occur in a river delta. Terrestrial molluscs (Vallonia and 
Deroceras) of the studied association likely preferred wet conditions and dense vegetation and, therefore, we suppose that the banks of the basin were covered with meadows, bushes, and deciduous forests. Similar conditions were reconstructed by Bogachev (1924, p. 82), but because he did not have stagnophile molluscs in his collections so he doubted that the water body was overgrown.

Bogachev (1924, p. 82) assumed a slight salinity of the water and suggested an existence of a liman (lagoon) or even marine conditions during the accumulation of the deposits. Indeed, both Viviparidae and Lithoglyphus are able to tolerate low salinity which may exist in deltas of modern rivers, for example, Don and Volga Rivers, but the core of the assemblage is quite typical for a freshwater conditions.

\section{CONCLUSIONS}

Two mollusc associations from the Morskaya 2 site were studied. The first assemblage is represented by the Middle Sarmatian (Bessarabian) marine molluscs species. The second complex consists of terrestrial and freshwater forms, as well as of redeposited marine, freshwater, and terrestrial molluscs. The freshwater molluscs are represented by the genera Lymnaea (Figure 5.6), Gyraulus, Borysthenia, Lithoglyphus, Viviparus, Sphaerium, and Pisidium. The terrestrial species are represented by Helicodiscus, Vallonia, Helicella (Figure 6.1) and Agriolimacidae. The following marine Bessarabian forms were redeposited from layers 1 and 2: Blinia cf. angulata, Gibbula (Sarmatigibbula) podolica, Gibbula (Gibbula) pseudoangulata, Gibbula sp. (Figure 7.4, 7.6), Barbotella intermedia, Dorsanum sp. (Figure 8.1), Hydrobia elongata, Hydrobia enikalensis (Figure 7.2), Pseudamnicola nympha, Acteocina lajonkareana, Retusa melitopolitana, Sarmatimactra fabreana, Veneridae, Plicatiforma fittoni fittoni, and Cardiidae (Figure 8.5-6). The reworked freshwater and terrestrial molluscs include Anisus cf. spirorbis and Vertigo sp. (Figure 7.1). The age of the nonmarine forms is presumably from the Bessarabian to Maeotian.

The age of the M2 assemblage was determined based on vertebrate remains, which are attributed to the late Turolian, (MN13) of the European biostratigraphic chart, which correlates to the late Miocene (Messinian), and the Maeotian regional stage. Ecological preferences of modern terrestrial and freshwater molluscan genera represented in the Morskaya 2 material indicate an overgrown freshwater body with a muddy bottom. It could be an oxbow or a floodplain lake with a recurring connection with a river as well as a shallow coastal part of a large river with a weak current. Since the terrestrial molluscs of the studied complex likely preferred wet conditions and dense vegetation, it can be assumed that the banks of the reservoir were covered with meadows, bushes, and leaved forests.

\section{ACKNOWLEDGEMENTS}

The authors are sincerely grateful to Dr. A.S. Tesakov and Dr. V.V. Titov for invitation into the project and unique materials from the Morskaya 2 site. The authors thank E.A. Shalaeva (Geological Institute Russian Academy of Sciences, Moscow) for helping with translation of this text. The authors thank the staff at the Palaeontological Institute of the Russian Academy of Sciences (PIN RAS, Moscow), namely, Dr. S.V. Popov, Dr. M.G. Sladkovskaya, Dr. I.A. Goncharova and Dr. L.B. Iljina for advices and the opportunity to compare our data with collections of the laboratory of molluscs (PIN RAS). The authors are grateful to Dr. A.S. Zastrozhnov (All-Russian Geological Institute, St. Petersburg) and the F.N. Chernyshev Central Scientific-Research Geological Museum for the access to the collections of N.S. Volkova. Many thanks to Dr. V.A. Prisyajnyuk (the Institute of Geological Sciences of the National Academy of Sciences of Ukraine, Kiev) for guidance in identification of Helicodiscus species and to Dr. T. Meijer (Netherlands) for gifting comparative collections. To Dr. A.S. Zastrozhnov and V.L. Shterkhun (AllRussian Geological Institute, St. Petersburg) and to the World Register of Marine Species (http:// www.marinespecies.org) for help in finding rare references. The authors thank Dr. Yu. Timirov and Dr. Yu. Lebedev, scientific researchers of the Institute of Molecular and Crystal Physics (Ufa Federal Research Center, Russian Academy of Sciences, Ufa), for providing the opportunity to make a photograph of mollusc shells on the Stemi 2000C Stereomicroscope (Carl Zeiss AG, Germany) and their help during the process. We are grateful to Nikolai Falelyukhin for the photos of the Barbotella and Vallonia. We thank the reviewers for their comments and critical remarks.

The work is supported by the Russian Foundation of Basic Research, projects No. 16-3550068/16 (scientific exchanges between Moscow and Ufa), and by the state theme AAAA-A17117030610119-6 of Geological Institute of RAS and State program N-0246-2019-0118 (preparations of fossils, computer work). 


\section{REFERENCES}

Aleksandrova, L.P., Vasiliev, Yu.M., Konstantiniva, N.A., Lebedeva, N.A., Nikiforova, K.V., Fedorov, P.V., and Chepalyga, A.L. 1984. Vnelednikovaya oblast', p. 95-158. In Krasnov, I.I. (ed.), Stratigrafiya SSSR. Chetvertichnaya Sistema. Polutom 2. Izdatel'stvo Nedra, Moskva. (In Russian)

Andreae, A. 1902. Zweiter Beitrag zur Binnenconchylienfauna des Miocäns von Oppeln in Schlesien. Mitteilungen aus dem Roemer-Museum Hildesheim, 18:1-31.

Anistratenko, O. and Anistratenko, V. 2007. Minute patellogastropods (Mollusca, Lottiidae) from the Middle Miocene of Paratethys. Acta Geologica Polonica, 57:343-376.

Anistratenko, O. and Anistratenko, V. 2012. Zoogeografiya i ekologiya srednesarmatskih gastropod Vostochnogo Paratetisa. Ruthenica, 22:115-134. (In Russian)

Anistratenko, O., Bandel, K., and Anistratenko, V. 2006. A new genus of patellogastropod with unusual protoconch from Miocene of Paratethys. Acta Palaeontologica Polonica, 51:155164.

Baker, H.B. 1927. Minute Mexican land snails. Proceedings of the Academy of Natural Sciences of Philadelphia, 79:223-246.

Berger, W. 1953. Die Bullaceen aus dem Tertiär des Beckens. Archiv für Molluskenkunde, 82:81129.

Berggren, W.A., Kent, D.V., Swisher, C.C., and Aubry, M.-P. 1995. A revised Cenozoic geochronology and chronostratigraphy, p. 129-212. In Berggren, W.A., Kent, D.V., Aubry, M.-P., and Hardenbol, J. (eds.), Geochronology, Time Scales and Global Stratigraphic Correlation: A Unified Temporal Framework for an Historical Geology. SEPM Special Publication 54. Society for Sedimentary Geology, Tulsa, Oklahoma. https://doi.org/10.2110/ pec.95.04.0129

Bogachev, V.V. 1910. Predvaritel'nyj otchet o geologicheskikh issledovaniyakh v 1907 i 1908 godakh. Izvestiya geologicheskogo komiteta, 29:765-837. (In Russian)

Bogachev, V.V. 1924. Presnovodnaya fauna Evrazii. Chast' 1. Tipografiya im. Gutenberga, Leningrad. (In Russian)

Bogachev, V.V. 1961. Materialy k istorii presnovodnoj fauny Evrazii. Izdatel'stvo Akademii Nauk USSR, Kiev. (In Russian)

Bogachev, V.V. and Shishkina A.I. 1919. Putevoditel' dlya geologicheskikh ekskursij v zemle Vsevelikogo Vojska Donskogo: Okrestnosti g. Taganroga. Tipografiya Upravlenij Artilerii Vevelikogo Vojska Donskogo, Novocherkassk. (In Russian)

Bouchet, P., Rocroi. J.P., Hausdorf, B., Kaim, A., Kano, Y., Nützel, A., Parkhaev, P., Schrödl, M., and Strong, E.E. 2017. Revised classification, nomenclator and typification of gastropod and monoplacophoran families. Malacologia, 61(1-2):1-526.

Brown, T. 1827. Illustrations of the Conchology of Great Britain and Ireland. Drawn from Nature. W.H. Lizars and D. Lizars, Edinburgh and S. Highley, London.

Charpentier, J. de 1837. Catalogue des mollusque terrestres et fluviatiles de la Suisse. Neue Denkschriften der Allgemeinen Schweizerischen Gesellschaft für die Gesammten Naturwissenschaften, 1:1-28.

Chepalyga, A.L. and Sidnev, A.V. 1983. Mollyuski Sultanaevskogo i Yulushevskogo razrezov, p. 54-94. In Yusupov, Yu.M. and Yachemovitch, V.L. (ed.), Fauna i flora pliotsena i pleistotsena. Izdatel'stvo Nauka, Moskva. (In Russian)

Chiamenti, A. 1900. Contribuzione alio studio della Malacofauna Adriatica. Nota sulla famiglia della Veneridae, e della Petricolidae. Rivista Italiana di Scienze Naturali, 20:9-15.

Cobălcescu, G. 1883. Studii geologice şi paleontologice asupra unor tărâmuri terţiare din unele părţi ale României. Memoriile Geologice ale Scólei Militare din laşi, 1:1-161.

Cohen, K.M., Finney, S.C., Gibbard, P.L., and Fan, J.-X. 2013. The ICS International Chronostratigraphic Chart. Episodes, 36:199-204.

Cossmann, M. 1918. Essais de paléoconchyliologie comperée. Onzième livraison. Chez l'auteur, Paris.

Cuvier, G. 1797. Tableau élémentaire de l'histoire naturelle des animaux. Baudouin, imprimeur du Corps législatif et de l'Institut national, Paris. 
Danilovskiy, I.V. 1955. Opornyj litologo-stratigraficheskij razrez otlozhenij skandinavskogo oledeneniya Russkoj ravniny i rukovodyashhie chetvertichnye mollyuski. Izdatel'stvo Gosgeoltechizdat, Moskva. (In Russian)

Davitashvili, L.Sh. 1932. Sarmatskij yarus. Gosudarstvennoe tekhnicheskoe izdatel'stvo, Moskva. (In Russian)

de Basterot, B. 1825. Description géologique du Bassin tertiaire du Sud-Ouest de la France. Mémoires de la Société d'Histoire Naturelle de Paris, 2(2):1-100.

d’Orbigny, L. 1844. Paléontologie du Voyage de M. Hommaire de Hell, p. 417-496. In Hommaire de Hell, M. (ed.), Les steppes de la mer Caspienne, le Caucase, la Crimée et la Russie méridionale. Voyage pittoresque, historique et scientifique, T. 3. P. Bertrand, Paris.

Deshayes, G.P. 1838. Description des coquilles fossiles recueillies en Crimée par M. de Verneuil, et observations générales à leur sujet. Mémoires de la Société géologique de France, Série 1, 3:37-69.

Du Bois de Montpéreux, F. 1831. Conchiologie Fossile et Aperçu Géognostique des Formations du Plateau Wolhyni-Podolien. Simon Schropp, Berlin.

Eichwald, E. 1830. Naturhistorische Skizze von Lithauen, Volhynien und Podolien in Geognostisch-mineralogischer, Botanischer und Zoologischer Hinsicht. Joseph Zawadzki, Vilnius.

Eichwald, E. 1850. Paleontologiya Rossii. Opisanie mollasovoj i namyvnoj formatsii. Tipografiya E. Pratsa, Sankt-Peterburg. (In Russian)

Eichwald, E. 1853. Lethaea Rossica ou Paléontologie de la Russie, décrite et figurée. Troisième volume. Dernière période. Schweizerbart, Stuttgart.

Falkner, G., Ripken, T.E.J., and Falkner, M. 2002. Mollusques continentaux de France. Liste de référence annotée et bibliographie. Collection Patrimoines Naturels, 52:1-350.

Fejfar, O., Heinrich, W.-D., and Lindsay, E.H. 1998. Updating the Neogene rodent biochronology in Europe. Mededelingen Nederlands Instituut voor Toegepaste Geowetenschappen TNO, 60:533-554.

Férussac, J.B.L. d'Audebard de, and Férussac, A.E.J.P.J.F. d'Audebard de 1807. Essai d'une méthode conchyliologique. De L'Imprimerie De Delance, Paris.

Friedberg, W. 1911-1928. Mięczaki mioceńskie ziem Polskich (Mollusca miocaenica Poloniae). I. Ślimaki i łódkonogi (Gastropoda et Scaphopoda). Nakładem Muzeum imienia Dzieduszyckich we Lwowie, Lwów i Poznań.

Geological Map of the southern Federal district of the Russian Federation 2013. A.P. Karpinsky Russian Geological Research Institute (VSEGEI), GIS Atlas of Geological Maps of Russia.

Gittenberger, E., Janssen, A.W., Kuijper, W.J., Kuiper, J.G.J., Meijer, T., Velde, G. Van der, and Vries, J.N. de. 1998. De Nederlandse zoetwatermollusken. Recente en fossiele weekdieren uit zoet en brak water. Nederlandse Fauna 2. Nationaal Natuurhistorisch Museum Naturalis, KNNV Uitgeverij \& EIS-Nederland, Leiden.

Glöer, P. 2002. Die Süßwassergastropoden Nord- und Mitteleuropas. Bestimmungsschlüssel, Lebensweise, Verbreitung. Die Tierwelt Deutschlands. Teil 73. Conchbooks, Hackenheim.

Goldfuss, G.A. 1841. Petrefacta Germaniæ tam ea: quae in Museo Universitatis Regiae Borussicae Fridericiae Wilhelmiae Rhenanae servantur quam alia quaecunque in Museis Hoeninghusiano Muensteriano aliisque extant, iconibus et descriptionibus illustrata, II (4). Arnz \& Co., Düsseldorf.

Gozhyk, P.F. and Prisyazhnyuk, V.A. 1978. Presnovodnye i nazemnye mollyuski miotsena Pravoberezhnoj Ukrainy. Izdatel'stvo Naukova Dumka, Kiev. (In Russian)

Gray, J.E. 1840. Shells of molluscous animals, p. 105-152. In Gray, J.E. (ed.), Synopsis of the Contents of the British Museum, 42nd ed. G. Woodfall, London.

Gray, J.E. 1847. A list of the genera of recent Mollusca, their synonyma and types. Proceedings of the Zoological Society of London, 15:129-242.

Gray, J.E. 1857. Guide to the Systematic Distribution of Mollusca in the British Museum, Part I. Taylor \& Francis, London.

Gromov, V.I. 1948. Paleontologicheskoe i arkheologicheskoe obosnovanie stratigrafii kontinental'nyh otlozhenij chetvertichnogo perioda na territirii SSSR (mlekopitayushhie, paleolit). Izdatel'stvo Akademii Nauk SSSR, Moskva. (In Russian)

Hartmann, W. 1821. System der Erd- und Flußschnecken der Schweiz. Mit vergleichender Aufzählung aller auch in den benachbarten Ländern, Deutschland, Frankreich und Italien sich vorfindenden Arten. Neue Alpina, 1:194-268. 
Harzhauser, M. and Neubauer, T.A. 2018. Opole (Poland) - a key locality for middle Miocene terrestrial mollusc faunas. Bulletin of Geosciences, 93:71-146. https://doi.org/10.3140/ bull.geosci.1692.

Harzhauser, M., Neubauer, T.A., Georgopoulou, E., Esu, D., D‘Amico, C., Pavia, G., Giuntelli, P., and Carnevale, G. 2015. Late Messinian continental and Lago-Mare gastropods from the Tertiary Piedmont Basin, NW Italy. Bollettino della Società Paleontologica Italiana, 54:1-53.

Hilgen, F., Lourens, L., and Van Dam, J. 2012. The Neogene period, p. 923-978. In Gradstein, F., Ogg, J.G., Schmitz, M.D., and Ogg, G.M. (ed.), The Geologic Time Scale. Elsevier, Amsterdam.

Hörnes, M. 1856. Die fossilen Mollusken des Tertiär-Beckens von Wien. I. Univalven. Abhandlungen der Kaiserlich-Königlichen Geologischen Reichsanstalt, 3:461-736.

Iljina, L.B. 1993. Opredelitel' morskikh srednemiotsenovykh gastropod Yugo-Zapadnoj Evrazii. Izdatel'stvo Nauka, Moskva. (In Russian)

Iljina, L.B., Nevesskaya, L.A., and Paramonova, N.P. 1976. Zakonomernosti razvitiya mollyuskov v opresnennykh bassejnakh neogena Evrazii. Izdatel'stvo Nauka, Moskva. (In Russian)

Khmelevskaya, L.K. 1927. K voprosu o vozraste i genezise kososloistykh peskov okrestnostej g. Rostova-na-Donu. Izvestiya Severo-Kavkazskogo gosudarstvennogo universiteta, 2(12):2529.

Kirillina, S.V. 1960. Mollyuski iz nizkikh terras rek Bashkirskogo Predural'ya. Voprosy geologii vostochnoj okrainy Russkoj platformy i Yuzhnogo Urala. Pliotsen i plejstotsen, 5:145-186. (In Russian)

Kolesnikov, V.P. 1929. O sarmatskikh predstavitelyakh semejstva Cardidae. Trudy Geologicheskogo muzeya Akademii nauk SSSR, 5:1-64. (In Russian)

Kolesnikov, V.P. 1930. O sarmatskikh predstavitelyakh semejstva Trochidae. Trudy Geologicheskogo muzeya Akademii nauk SSSR, 6:37-67. (In Russian)

Kolesnikov, V.P. 1932. Buccinidae sarmata. Trudy Geologicheskogo Instituta Akademii Nauk SSSR, 2:65-134. (In Russian)

Kolesnikov V.P. 1934. Fatsyi sarmata Tanaisskogo zaliva. Izvestiya Akademii nauk SSSR. VII seriya. Otdelenie matematicheskikh i estestvennykh nauk, 2-3:217-234. (In Russian)

Kolesnikov, V.P. 1935. Sarmatskoe mollyuski. Izdatel'stvo Akademii Nauk SSSR, Leningrad. (In Russian)

Kolesnikov, V.P. 1939. K sistematike sarmatskikh gastropod. Doklady Akademii Nauk SSSR, 25:701-704. (In Russian)

Kolesnikov, V.P. 1940. Verkhnij miotsen, p. 229-373. In Arkhangel'skij, A.D. (ed.), Stratigrafiya SSSR. Neogen SSSR. Izdatel'stvo Akademii Nauk SSSR, Moskva-Leningrad. (In Russian)

Korobkov, I.A. 1954. Spravochnil i metodicheskoe rukovodstvo po tretichnym molluskam. Plastinchatozhabernye. Gostoptekhizdat, Leningrad. (In Russian)

Korobkov, I.A. 1978. Paleontologicheskie opisaniya. Izdatel'stvo Nedra, Leningrad. (In Russian)

Kojumdgieva, E. 1969. Sarmat. Fosilite na Blgariya, VIII. Izdatel'stvo Blgarskoy Akademii Nauk. (In Bulgarian).

Krijgsman W., Tesakov, A., Yanina, T., Lazarev, S., Danukalova, G., Van Baak, C.G.C., Agustí, J., Alçiçek, M.C., Aliyeva, E., Bista, D., Bruch, A., Büyükmeriç, Y., Bukhsianidze, M., Flecker, R., Frolov, P., Hoyle, T.M., Jorissen, E.L., Kirscher, U., Koriche, S.A., Kroonenberg, S.B., Lordkipanidze, D., Oms, O., Rausch, L., Singarayer, J., Stoica, M., van de Velde, S., Titov, V.V., and Wesselingh, F.P. 2019. Quaternary time scales for the Pontocaspian domain: Interbasinal connectivity and faunal evolution. Earth-Science Reviews, 188:1-40. https:// doi.org/10.1016/j.earscirev.2018.10.013

Kravchenko, E.N. 2011. Nassariidae Miotsena Moldavskogo Pridnestrov'ya. Abridged version of PhD Thesis, Institut geologicheskikh nauk Natsional'noj Akademii Nauk Ukrainy, Kiev, Ukraine. (In Russian)

Lamarck, J.B.M. de 1799. Prodrome d'une nouvelle classification des coquilles. Mémoires de la Société d'Histoire Naturelle de Paris, 1:63-91.

Lamarck, J.B.M. de 1809. Philosophie Zoologique, Volume 1. Dentu, Paris.

Lamarck, J.B.M. de 1818. Histoire naturelle des animaux sans vertèbres. Tome cinquième. Deterville/Verdière, Paris.

Likharev, I.M. and Rammelmeyer, E.S. 1952. Nazemnye mollyuski fauny SSSR. Izdatel'stvo Akademii Nauk SSSR, Moskva - Leningrad. (In Russian)

Likharev, I.M. and Wiktor A.I. 1980. Slizni fauny SSSR i sopredel'nykh stran (Gastropoda terrestria nuda). Fauna SSSR, III(5):1-438. (In Russian) 
Lindholm, W.A. 1914. Miszellen zur Malakozoologie des Russischen Reiches. I-XIII. Annuaire du Musée Zoologique de l'Académie Impériale des Sciences de St.-Pétersbourg, 18(1):51167.

Lindholm, W.A. 1932. Mollyuski iz srednepliotsenovykh otlozhenij yugo-zapadnoj Sibiri. Gosudarstvennoe geologo-razvedochnoe izdatel'stvo, Leningrad - Moskva. (In Russian)

Linnaeus, C. 1758. Systema Naturae. Editio decima, reformata. Laurentius Salvius, Holmiae. https://doi.org/10.5962/bhl.title.542

Ložek, V. 1964. Quartärmollusken der Tschechoslowakei. Geologische Zentralanstalt im Verlag der Tschechoslowakischen Akademie der Wissenschaften, Praha.

Lukeneder, S., Zuschin, M., Harzhauser, M., and Mandic, O. 2011. Spatiotemporal signals and palaeoenvironments of endemic molluscan assemblages in the marine system of the Sarmatian Paratethys. Acta Palaeontologica Polonica, 56:767-784. https://www.doi.org/ 10.4202/app.2010.0046

Malchevskaya, V.M. 1985. Katalog golotipov vidov fauny i flory, khranyashhikhsya v TsNIGR muzee. Chast' 2 mezo-kajnozoj. Leningradskaya kartograficheskaya fabrika VSEGEI, Leningrad. (In Russian)

Mangikian, T.A. 1929. O kuyal'nitskikh otlozheniyakh okrestnostej Odessy. Vestnik ukrainskogo otdeleniya Geolkoma, 14:161-192. (In Russian)

Mangikian, T.A. 1931. Kratkij obzor iskopaemykh palyudin yuga SSSR i Bessarabii. Geologicheskoe izdatel'stvo glavnogo geologorazvedochnogo upravleniya, Moskva Leningrad. (In Russian)

Mein, P. 1975. Résultats du Groupe de Travail des Vertébrés, p. 78-81. In Seneš, J. (ed.), Report on the Activity of the RCMNS Working Groups. Slovak Academy of Sciences, Bratislava.

Merklin, R.L. and Nevesskaya, L.A. 1955. Opredelitel' dvustvorchatykh mollyuskov miotsena Turkmenii i zapadnogo Kazakhstana. Izdatel'stvo Akademii Nauk SSSR, Moskva. (In Russian)

Montfort, P. 1810. Conchyliologie systématique et classification méthodique des coquilles. Schoell, Paris.

Morse, E.S. 1864. Observations on the terrestrial Pulmonifera of Maine, including a catalogue of all the species of terrestrial and fluviatile Mollusca known to inhabit the state. Journal of the Portland Society of Natural History, 1(1):1-63.

Moskvitin, A.I. 1932. Chetvertichnye otlozheniya okrestnostej Taganroga, p. 185-196. In Mirchink, G.F. (ed.), Putevoditel' ekskursij vtoroj chetvertichno-geologicheskoj konferentsii. Assotsiatsiya dlya izucheniya chetvertichnykh otlozhenij Evropy. Gosudarstvennoe nauchnotekhnicheskoe geologo-razvedochnoe izdatel'stvo, Leningrad - Moskva. (In Russian)

Müller, O.F. 1774. Vermium Terrestrium et Fluviatilium, seu Animalium Infusoriorum, Helminthicorum, et Testaecorum, non Marinorum, Succincta Historia. Heineck \& Faber, Havniæ (Copenhagen) \& Lipsiæ (Leipzig).

Murchison, R.I., Verneuil, E., and de Keyserling, A. 1845. Géologie de la Russie d'Europe et des montagnes de l'Oural. Vol. II. Paléontologie. P. Bertrand, Paris.

Neubauer, T.A., Harzhauser, M., and Mandic, O. 2013. Phenotypic evolution in a venerid bivalve species lineage from the late Middle Miocene Central Paratethys Sea: a multi-approach morphometric analysis. Biological Journal of the Linnean Society, 110:320-334. https:// doi.org/10.1111/bij.12120.

Nevesskaya, L.A., Goncharova, I.A., Paramonova, N.P., Popov, S.V., Babak, E.V., Bagdasaryan, K.G., and Voronina, A.A. 1993. Opredelitel' miotsenovykh dvustvorchatykh mollyuskov YugoZapadnoj Evrazii. Izdatel'stvo Nauka, Moskva. (In Russian)

Nevesskaya, L.A., Paramonova, N.P., and Popov, S.V. 2001. History of Lymnocardiinae (Bivalvia, Cardiidae). Paleontological Journal, 35:147-217.

Nevesskaya, L.A., Kovalenko, E.I., Beluzhenko, E.V., Popov, S.V., Goncharova, I.A., Danukalova, G.A., Zhidovinov, N.Ya., Zajtsev, A.V., Zastrozhnov, A.S., Iljina, L.B., Paramonova, N.P., Pinchuk, T.N., Pis'mennaya, N.S., Agadzhanyan, A.K., Lopatin, A.V., and Trubikhin, V.M. 2004. Ob"yasnitel'naya zapiska k unifitsirovannoj regional'noj stratigraficheskoj skheme neogenovykh otlozhenij yuzhnykh regionov Evropejsloj Rossii. Izdatel'stvo Paleontologicheskogo Instituta, Moskva. (In Russian)

Nevesskaya, L.A., Kovalenko, E.I., Beluzhenko, E.V., Popov, S.V., Goncharova, I.A., Danukalova, G.A., Zhidovinov, N.Ya., Zajtsev, A.V., Zastrozhnov, A.S., Pinchuk, T.N. Iljina, L.B., Paramonova, N.P., Pis'mennaya, N.S., and Khodkarian, S.A. 2005. Regional'naya 
stratigraficheskaya skhema neogena yuga Evropejskoj chasti Rossii. Otechestvennaya geologiya, 4:47-59. (In Russian)

Nevesskaya, L.A., Popov, S.V., Goncharova, I.A., Guzhov, A.V., Yanin, B.T., Polubotko, I.V., Byakov, A.S., and Gavrilova, V.A. 2013. Dvusvorchatye mollyuski Rossii i sopredel'nykh stran v fanerosoe. Izdatel'stvo Nauchnyj mir, Moskva. (In Russian)

Paulucci, M. 1878. Matériaux pour servir à l'étude de la faune malacologique terrestre et fluviatile de l'Italie et de ses iles. Librairie F. Savy, Paris.

Pfeiffer, C. 1821. Naturgeschichte Deutscher Land- und Süsswasser-Mollusken. 1. LandesIndustrie-Comptoir, Weimar.

Pfeiffer C. 1828. Naturgeschichte Deutscher Land- und Süsswasser Mollusken. 3. LandesIndustrie-Comptoir, Weimar.

Pogrebnov, N.I., Potapov, I.I., and Smirnov, B.V. 1970. Tektonika, p. 515-578. In Sidorenko, A.V. (ed.), Geologiya SSSR. Tom XLVI. Rostovskaya, Volgogradskaya, Astrakhanskaya oblasti i Kalmytskaya ASSR. Izdatel'stvo Nedra, Moskva. (In Russian)

Popov, G.I. 1962. O sootnosheniyakh kontinental'nykh I morskikh verkhnepliotsenivykh otlozhenij yuga i yugo-vostoka Evropejskoj chasti SSSR v svyazi s voprosom o nizhnej granitse chetvertichnigo perioda. Trudy komissii po izucheniyu chetvertichnogo perioda, 20:92-97. (In Russian)

Popov, G.I. 1965. Pliotsenovye presnovodnye mollyuski Bashkirskogo Predural'ya i ikh stratigraficheskoe znachenie, p. 210-229. In Yachemovitch, V.L. (ed.), Antropogen Yuzhnogo Urala. Izdatel'stvo Nauka, Moskva. (In Russian)

Popov, G.I. 1972. Mollyuski, p. 98-118. In Yachemovitch, V.L. (ed.), Fauna i flora Akkulaevo (opornyj razrez srednego akchagyla - srednego apsherona Bashkirii). Izdatel'stvo Bashkirskogo Filiala Akademii Nauk SSSR, Ufa. (In Russian)

Popov, G.I. 1983. Plejstotsen Chernomorsko-Kaspijskikh prolivov. Izdatel'stvo Nauka, Moskva. (In Russian)

Popov, S.V., Rögl, F., Rozanov, A.Y., Steininger, F.F., Shcherba, I.G., and Kovac, M. 2004. Lithological-Paleogeographic Maps of Paratethys: 10 Maps Late Eocene to Pliocene. Courier Forschungsinstitut Senckenberg, 250, 1-46.

Popov, S.V., Shcherba, I.G., Ilyina, L.B., Nevesskaya, L.A., Paramonova, N.P., Khondkarian, S.O., and Magyar, I. 2006. Late Miocene to Pliocene palaeogeography of the Paratethys and its relation to the Mediterranean. Palaeogeography Palaeoclimatology Palaeoecology, 238:91-106. https://doi.org/10.1016/j.palaeo.2006.03.020

Prisyazhnyuk, V.A. 1972. Nekotorye predstaviteli nazemnykh mollyuskov v sarmatskikh otlozheniyakh Volyno-Podolii. Geologicheskij Zhurnal, 32(1):130-133. (In Russian)

Radovanović, S. and Pavlović, P. 1893. Über die geologischen Verhältnisse des serbischen Theils des unteren Timok-Becken. Annales Geologiques de la Peninsule Balkanique, 4:89132.

Rafinesque, C.S. 1815. Analyse de la Nature ou Tableau de l'univers et des Corps Organisés. Self-published (at the expense of the Author), Palermo.

Risso, A. 1826. Histoire naturelle des principales productions de l'Europe Méridionale et particulièrement de celles des environs de Nice et des Alpes Maritimes. Levrault, Paris.

Rodzyanko, G.N. 1981. Stratigrafiya pliotsenovykh otlozhenij severo-vostochnogo Priazov'ya, Nizhnego Dona, Primanych'ya, Ergenej i Volgo-Khoperskogo mezhdurech'ya, p. 139-148. In Kamaletdinov M.A. and Yachemovitch V.L. (ed.), Pliotsen i pleistotsen Volgo-Ural'skoj oblasti. Izdatel'stvo Nauka, Moskva. (In Russian)

Rodzyanko, G.N. 1986. Yuzhnaya chast' tsentral'nykh rajonov Vostochno-Evropejskoj platformy, p. 268-287. In Muratov, M.V. and Nevesskaya, L.A. (ed.), Stratigrafiya SSSR. Neogenovaya Sistema. Polutom 1. Izdatel'stvo Nedra, Moskva. (In Russian)

Roshka, V.Kh. 1986. Nazemnye element mollyuskovoj fauny nizhnego sarmata u s. Bursuk Moldavskoj SSR, p. 35-53. In Nevesskaya L.A. (ed.), Paleontologo-stratigraficheskie Issledovaniya Mezozoya i Kajnozoya Mezhdurech'ya Dnestr - Prut. Izdatel'stvo Shtiintsa, Kishinev. (In Russian)

Sanko, A.F. 2007. Chetvertichnye presnovodnye mollyuski Belorusu i smezhnykh regionov Rossii, Litvy i Pol'shi (atlas-opredelitel'). Izdatel'stvo Natsional'noj Akademii Nauk Belorusi, Minsk. (In Russian) 
Sars, G.O. 1878. Bidrag til kundskaben om Norges arktiske fauna, I. Mollusca regionis arcticae Norvegiae. Brøgger, Christiania.

Schlickum, W.R. 1978. Helicodiscus (Hebetodiscus), ein altes europäisches Faunenelement. Archiv für Molluskenkunde, 110:67-70.

Schmidt, F.J. 1847. Systematisches Verzeichniss der in der Provinz Krain vorkommenden Landund Süsswasser-Conchylien, mit Angabe der Fund-Orte. Blasnik, Laibach.

Schneider, S., Mandic, O., and Harzhauser, M. 2013. Preserved colour pattern in Polititapes tricuspis (Eichwald, 1829) (Bivalvia: Veneridae) from the Sarmatian holostratotype at Nexing (Lower Austria). Neues Jahrbuch für Geologie und Paläontologie, 268:191-197. https:// doi.org/10.1127/0077-7749/2013/0326

Scopoli, J.A. 1777. Introdvctio ad historiam natvralem sistens genera lapidvm, plantarvm, et animalivm hactenvs detecta, caracteribvs essentialibvs donata, in tribvs divisa, svbinde ad leges natvrae. Gerle, Pragae.

Sepkoski, J.J. Jr., 2002. A compendium of fossil marine animal genera. Bulletins of American Paleontology, 363:1-560.

Shileyko, A.A., 1984. Nazemnye mollyuski podotryada Pupillina fauny SSSR (Gastropoda, Pulmonata, Geophila). Izdatel'stvo Nauka, Leningrad. (In Russian)

Sinzov, I.F. 1875. Opisanie novykh i maloissledovannykh form rakovin iz tretichnykh obrazovanij Novorossii. Zapiski Novorossijskogo obshhestva estestvoispytatelej, 3(2):1-61. (In Russian)

Sinzov, I. 1880. Opisaniye novykh i maloissledovannykh form rakovin iz tretichnykh obrazovaniy Novorossii. Zapiski novorossiiskoe obshchestvo estestvoispytatelei, 8:1-16. (In Russian)

Sladkovskaya, M.G. 2017. Trochidae (Gastropoda) from the Sarmatian Basin of the Eastern Paratethys. Paleontological Journal, 51:1453-1583. https://doi.org/10.1134/ s0031030117140039

Sokolov, N.A. 1899. Sloi s Venus konkensis. Sredizemnomorskie otlozheniya na r. Konke. Trudy Geologicheskogo Kommiteta, 9(5):1-96. (In Russian)

Starobogatov, Ya.I. 1977. Klass dvustvorchatye mollyuski Bivalvia, p. 123-151. In Kutikova, L.A. and Starobogatov, Ya.I. (ed.), Opredelitel' presnovodnykh bespozvonochnykh evropejskoj chasti SSSR (plankton i bentos). Gidrometeoizdat, Leningrad. (In Russian)

Stefanescu, S. 1896. Études sur les Terrains tertiaires de Roumanie. Contribution a l'étude des faunes sarmatique, pontique et levantine. Mémoirs de la Société Géologique de France, Mémoir 15. Paléontologique, 6(2-3):1-147.

Steklov, A.A. 1966. Nazemnye mollyuski neogena Predkavkaz'ya i ikh stratigraficheskoe znachenie. Izdatel'stvo Nauka, Moskva. (In Russian)

Stimpson, W. 1865. Researches upon the Hydrobiinae and allied forms: chiefly made from materials in the Museum of the Smithsonian Institution. Smithsonian Miscellaneous Collections, 7:1-59.

Studer, S. 1820. Kurzes Verzeichniss der bis jetzt in unserm Vaterlande entdeckten Conchylien. Naturwissenschaftlicher Anzeiger der Allgemeinen Schweizerischen Gesellschaft für die Gesammten Naturwissenschaften, 3(11):83-90, 91-94.

Stworzewicz, E. and Prisyazhnyuk, V.A. 1997. Helicodiscus (Helicodiscus) depressus (Eichwald, 1830) or Helicodiscus (Helicodiscus) parallelus (Say, 1821) in the Neogene of Europe (Gastropoda: Pulmonata: Endodontidae). Genus, 8(1):197-204.

Stworzewicz, E., Prisyazhnyuk, V.A., and Górka, M. 2013. Systematic and palaeoecological study of Miocene terrestrial gastropods from Zwierzyniec (southern Poland). Annales Societatis Geologorum Poloniae, 83:179-200.

Tesakov, A.S., Dodonov, A.E., Titov, V.V., and Trubikhin, V.M. 2007. Plio-Pleistocene geological record and small mammal faunas, eastern shore of the Azov Sea, Southern European Russia. Quaternary International, 160:57-69. https://doi.org/10.1016/j.quaint.2006.09.009.

Thiele, J. 1925. Gastropoden der Deutschen Tiefsee-Expedition. II. Teil. Wissenschaftliche Ergebnisse der Deutschen Tiefsee-Expedition auf dem Dampfer "Valdivia" 1898-1899, $17(2): 35-382$.

Titov, V.V. 2008. Krupnye mlekopitayushhie pozdnego pliotsena Severo-Vostochnogo Priazov'ya. Izdatel'stvo YUNTS RAN, Rostov-na-Donu. (In Russian)

Titov, V.V. and Tesakov, A.S. 2013. Late Miocene (Turolian) vertebrate faunas of the southern European Russia, p. 536-543. In Wang, X., Flynn, L.J., and Fortelius, M. (eds.), Fossil Mammals of Asia: Neogene Biostratigraphy and Chronology. Columbia University Press, New York. https://doi.org/10.7312/columbia/9780231150125.003.0024 
Titov, V.V., Tesakov, A.S., Danilov, I.G., Danukalova, G.A., Mashenko, E.N., Panteleev, A.V., Sotnikova, M.V., and Sychevskaya, E.K. 2006. The first representative vertebrate fauna from the late Miocene of Southern European Russia. Doklady Akademii Nauk, 411:715-717. https://doi.org/10.1134/s001249660606024x

Toula, F. 1892. Geologische Untersuchungen im östlichen Balkan und in anderen Theilen von Bulgarien und Ostrumelien (II Abtheilung). Denkschriften der kaiserlichen Akademie der Wissenschaften Mathematisch-Naturwissenschaftlichen Classe, 59:409-478.

Tryon, G.W. 1866. Book review of researches upon the Hydrobiinae and allied forms by Dr. Wm. Stimpson, 8 vol. Smithsonian Institution, Washington D.C., August 1865. 58 pp. American Journal of Conchology, 2:152-158.

Turton, W. 1822. Conchylia insularum britannicarum. Nattali and Leicester, London.

Vangengeim, E.A. and Tesakov, A.S. 2008. Mestonakhozhdeniya mlekopitaushikh me'otisa Vostochnogo Paratetisa: ih mesto v magnitokhronologicheskoj i evropejskoj kontinental'noj shkalakh. Stratigrafiya. Geologicheskaya korrelyatsyya, 16(4):95-109. (In Russian)

Vasiliev, Yu.M. 1969. Formirovanie antropogenovykh otlozhenij lednikovij i vnelednikovoj zony. Izdatel'stvo Nauka, Moskva. (In Russian)

Volkova, N.S. 1939. K stratigafii verkhnetretichnykh otlozhenij Stavropolya. Trudy po geologii i poleznym iskopaemym Severnogo Kavkaza, IV:3-28. (In Russian)

Volkova, N.S. 1974. Polevoj atlas fauny mollyuskov neogenovykh otlozhenij yuga SSSR. Izdatel'stvo Nauka, Leningrad. (In Russian)

Wagner, H. 1935. Magyarorszag, hovatorszag es Dalmacia hazatlan csigai. Die Nacktschnecken Ungarns, Croatiens und Dalmatiens. Annales Historico-Naturales Musei Nationalis Hungarici, Pars zoologica, 29:169-212.

Wenz, W. 1942. Die Mollusken des Pliozäns der rumänischen Erdöl-Gebiete als Leitversteinerungen für die Aufschluß-Arbeiten. Senckenbergiana, 24:1-293.

Wenz, W. and Edlauer, A. 1942. Die Molluskenfauna der oberpontischen Süsswassermergel von Eichkogel bei Mödling. Archiv für Molluskenkunde, 74:82-98.

Westerlund, C.A. 1885. Fauna der in der paläarctischen Region lebenden Binnenconchylien. R. Friedländer \& Sohn, Berlin. https://doi.org/10.5962/bhl.title.10301

Wüst, E. 1901. Untersuchungen über das Pliozän und das Älteste Pleistozän Thüringens, nördlich vom Thüringer Walde und westlich von der Saale. Abhandlungen der naturforschenden Gesellschaft Halle, 23:19-368.

Yanakevich, A.N. 1987. Srednemiotsenovye bryukhonogie mollyuski Moldavii i usloviya ikh sushestvovaniya. Izdatel'stvo Shtiintsa, Kishinev. (In Russian)

Zhadin, V.I. 1952. Mollyuski presnykh vod SSSR. Izdatel'stvo Akademii Nauk SSSR, Moskva Leningrad. (In Russian)

Zhizhchenko, B.P. 1936. Chokrakskie mollyuski. Izdatel'stvo Akademii Nauk SSSR, Moskva Leningrad. (In Russian)

Zykin, V.S. 2012. Stratigrafiya i e'volyutsiya prirodnoj sredy i klimata v pozdnem kajnozoe yuga Zapadnoj Sibiri. Izdatel'stvo Geo, Novosibirsk. (In Russian) 